\title{
Feeding various forages and live yeast culture on weaned dairy calf intake, growth, nutrient digestibility, and ruminal fermentation
}

\author{
L. K. Mitchell and A. J. Heinrichs* \\ Department of Animal Science, The Pennsylvania State University, University Park 16802
}

\begin{abstract}
The objective of this study was to determine effects of various forages and live yeast culture on intake, growth, nutrient digestibility, and ruminal fermentation of weaned dairy calves. Holstein calves $(\mathrm{n}=45)$ were randomly assigned to $2 \times 3$ factorial treatments: live yeast culture or no yeast and alfalfa haylage $(\mathrm{AH})$, corn silage (CS), or grass hay $(\mathrm{GH})$. Calves were weaned at 6 wk of age, housed individually, and studied from 7 to 16 wk of age. Rations, consisting of an $18 \%$ crude protein texturized grower (yeast or no yeast) and assigned forage, were offered as separate components until 9 wk of age. After 9 wk, diets were offered as a total mixed ration (TMR). Concentrate intake was capped at 2.25 $\mathrm{kg}$ of dry matter $(\mathrm{DM}) / \mathrm{d}$, and forage was offered ad libitum. The TMR contained equal forage neutral detergent fiber $(8 \pm 0.5 \%)$ on a DM basis for each basal diet. Calves were fed TMR to limit concentrate intake, and additional forage was offered ad libitum after 8 $\mathrm{h}$ if the entire TMR allotment was consumed. Total fecal collection (12 calves) was conducted for $4 \mathrm{~d}$ at 11 and $15 \mathrm{wk}$ of age. Feeds and feces were evaluated for DM, neutral detergent fiber, acid detergent fiber, and starch to calculate digestibility. On the last day of fecal collection, rumen samples were collected to evaluate $\mathrm{pH}$ and volatile fatty acid (VFA) profile. Metabolizable energy and DM intake was least for calves consuming $\mathrm{GH}$ compared with other forages. Forage intake (\% of DM intake) increased as calves aged ( $\mathrm{AH}=20$ to $44.4 \%$, CS $=24.5$ to $37.6 \%, \mathrm{GH}=11.3$ to $32.3 \%$ at 10 and $16 \mathrm{wk}$ of age, respectively). Calves on CS had the greatest average daily gain and empty body weight gain, and calves on GH had the least. Calves on GH tended to have the lowest final body weight. There were no differences in structural growth. Digestibility of DM decreased with age. Fiber digestibility was least for calves on CS, and starch digestibility was least for calves on AH. Mean and minimum rumen $\mathrm{pH}$ increased with age. Forage of-
\end{abstract}

Received March 5, 2020

Accepted May 15, 2020.

*Corresponding author: ajh@psu.edu fered changed VFA profile and there was an interaction between yeast and forage on VFA profile. These results indicated that recently weaned calves perform well on $\mathrm{AH}, \mathrm{CS}$, or GH and have minimal benefit from yeast supplementation. Feeding GH reduced weight gain, but all calves achieved a level of gain to meet growth goals for breeding and freshening. Furthermore, the ability to consume large portions of the ration as forage allows for more economical diets to be fed.

Key words: forage, weaned calf, yeast

\section{INTRODUCTION}

The most common forages found on US dairy farms are alfalfa hay or haylage, corn silage, and grass hay (USDA, 2014). Several studies on calves have evaluated the use of various forages and NDF sources including alfalfa hay, grass hay, beet pulp, cottonseed hulls, soy hulls, straw, ryegrass hay, barley straw, oat hay, triticale silage, and corn silage (Imani et al., 2017). However, most of these studies focus on the preweaning stage and evaluate calves for only 2 to 3 wk postweaning, when forage consumption is still quite low (Castells et al., 2012, 2013; Omidi-Mirzaei et al., 2018). Only a few studies have focused on postweaned calves, and roughages used were cottonseed hulls, grass hay, alfalfa hay, and straw (Hill et al., 2009b, 2010). There is a lack of data on feeding alfalfa haylage and corn silage to calves 8 to $16 \mathrm{wk}$ of age. It is clear that physical and chemical differences in these forages compared with each other and with grass hay should lead to differences in intake (Allen, 2000), which would in turn be expected to affect metabolism and growth.

Calves from 8 to 16 wk of age are rapidly changing physically in respect to their digestive systems. Feeding forage is recommended at this age, but there are limitations surrounding how much and of what quality these calves can consume and still meet growth goals (Heinrichs, 1996). Recent research has shown that energy available to a calf from calf starter is closely associated with cumulative intake of NFC as the animal ages due to the connection between NFC intake and rumen development, and that digestibility is maximized at ap- 
proximately $15 \mathrm{~kg}$ of cumulative NFC DMI (Quigley et al., 2019). The increase in available energy is indicative of rumen development and although time to reach 15 $\mathrm{kg}$ of cumulative NFC intake will vary based on health, milk feeding program, and calf starter composition, most calves should reach that intake level by 2 to $3 \mathrm{wk}$ postweaning. At that point, ration cost may be considered with care, given that calves accomplish desirable growth rates as gut fill may still be a factor. Feed is the largest cost associated with raising replacement heifers, which are the second or third largest expense on dairy farms (Heinrichs et al., 2013). Feeding increased levels of forage to weaned calves (approximately $8-16 \mathrm{wk}$ of age) may be an effective tool to reduce rearing costs. However, forage cannot be fed at the expense of growth goals. Hill et al. (2010) found that increasing forage levels in a TMR reduced ADG. However, calves in their study were fed as much as $9 \%$ wheat straw, $9 \%$ chopped grass hay, and $15 \%$ long alfalfa hay and accomplished ADG of 900, 1,090, and 1,070 g/d, respectively. Mitchell et al. (2020) started calves on a TMR containing $15 \%$ grass hay at 8 wk of age and reported ADG of $1,040 \mathrm{~g} / \mathrm{d}$ through $14 \mathrm{wk}$ of age. These growth rates are sufficient, if not more rapid than necessary, for these calves to accomplish desired weights at breeding and freshening. At the same time, inclusion of increased levels of forage allows for reduced feeding of concentrates. There is currently a lack of knowledge around how much forage calves from 8 to 16 wk of age can consume and its potential effects on growth.

Growth of the calf can also be affected by additives, such as yeast, to the diet. The addition of yeast culture to neonate dairy calf and adult cow rations has been in practice for a long time. However, the effects of yeast inclusion in calf rations have been inconsistent. Some have found yeast inclusion to increase DMI and ADG about 15\% (Lesmeister et al., 2004; Galvão et al., 2005), and others have seen no effect on DMI or ADG (Quigley et al., 1992; Magalhães et al., 2008). It has also been observed that yeast inclusion increased feed efficiency by increasing ADG but not DMI (Panda et al., 1995). However, that has not been observed by others (Quigley et al., 1992; Lesmeister et al., 2004; Magalhães et al., 2008). One of the more consistently reported effects of yeast is the reduction of diarrhea in young calves (Alugongo et al., 2017). A recent review by Alugongo et al. (2017) found 8 studies that reported reductions in diarrhea with yeast supplementation, and only 3 reported similar levels of diarrhea. It is important to note that studies involving yeast supplementation on calf intake, growth, and health have primarily focused on the preweaning stage (6-9 wk of age) and do not often track calves until 12 or 13 wk of age (Alugongo et al.,
2017). Yeast inclusion does not seem to have an effect on ruminal pH in calves (Xiao et al., 2016), though a meta-analysis covering all ruminants showed that yeast inclusion modestly increased rumen $\mathrm{pH}$ (Desnoyers et al., 2009).

In addition to $\mathrm{pH}$ effects, the effects of yeast on VFA profiles in young calves have been inconsistent, as some have observed increases in acetate but decreases in butyrate (Hučko et al., 2009), whereas others have seen no changes (Hill et al., 2009a). It has been proposed and demonstrated in vitro that yeast stimulates cellulolytic bacteria, thus enhancing fiber fermentability (Callaway and Martin, 1997; Robinson and Erasmus, 2009). Fiber digestibility was found to have a quadratic response on increasing yeast dose in heifers around 16 mo of age (Lascano et al., 2012), but research into yeast effects on digestibility in calves $<16$ mo of age is lacking. Ultimately, the effects of feeding yeast to young calves are inconsistent, and data that focus specifically on feeding yeast to postweaned calves are lacking (Alugongo et al., 2017).

In addition, it is known that 8- to 16 -wk-old calves can consume up to $15 \%$ long alfalfa hay or chopped grass hay and still accomplish adequate growth rates (Hill et al., 2010; Mitchell et al., 2020). However, it appears that calves in this age range may be able to consume even more forage and still accomplish desirable growth rates. Increased forage feeding would reduce ration cost, but forage cost is largely tied to forage availability on farm. Therefore, comparisons of the most common forages available on dairy farms need to be made for calves 8 to 16 wk of age. The objective of this study was to determine the effects of alfalfa haylage, corn silage, or grass hay and live yeast culture on weaned calf intake, growth, nutrient digestibility, and ruminal fermentation. We hypothesized that weaned calves would experience effects of yeast on intake or growth and perform well regardless of forage source and that forage source would affect intake, growth, nutrient digestibility, and ruminal fermentation.

\section{MATERIALS AND METHODS}

\section{Animals and Treatments}

The Pennsylvania State University Institutional Animal Care and Use Committee reviewed and approved all procedures used in this study (IACUC \#47347). Forty-eight Holstein calves used in a prior study evaluating the effects of live yeast culture (Y; Yea-Sacc 1026, Alltech Inc., Nicholasville, KY) or no yeast (NY) and once versus twice daily milk feeding were maintained on $\mathrm{Y}$ or NY treatments and randomly assigned by sex 
and prior treatment to 1 of 3 forages: alfalfa haylage $(\mathbf{A H})$, corn silage (CS), or grass hay $(\mathbf{G H})$. Forty-five calves (36 female; 9 male) were used for the growth and intake portion of the study. Treatments were arranged as a $2 \times 3$ factorial and resulted in 6 treatment groups: YAH $(\mathrm{n}=7)$, NYAH $(\mathrm{n}=8)$, YCS $(\mathrm{n}=8)$, NYCS $(\mathrm{n}$ $=7)$, YGH $(\mathrm{n}=8)$, and NYGH $(\mathrm{n}=7)$. Calves were studied from 7 to 16 wk of age. Twelve male calves $(\mathrm{n}=6$ per yeast treatment and 4 per forage; 9 from the original study plus 3 additional) were used for the digestibility and ruminal fermentation portion of the study. Male calves were surgically fitted with a $3-\mathrm{cm}$ rumen cannula at $7 \pm 3$ wk of age.

Previously, calves were offered $6 \mathrm{~L} / \mathrm{d}$ of pasteurized whole milk (Y or NY; once or twice daily milk feeding) through 5 wk and $3 \mathrm{~L} / \mathrm{d}$ until weaning at $6 \mathrm{wk}$. Texturized starter ( $\mathrm{Y}$ or NY; East Gate Feed and Grain, Reedsville, PA) was offered ad libitum starting at $3 \mathrm{~d}$ of age. Intake and growth did not differ in the first $6 \mathrm{wk}$ of age for calves fed milk once versus twice per day or Y versus NY (Saldana et al., 2019). Rations, consisting of a different texturized grower ( $\mathrm{Y}$ at $0.88 \mathrm{~g} / \mathrm{kg}$ or NY; Ridley Feeds Inc., Lancaster, PA) and assigned forage, were offered as separate components from 7 to 9 wk of age. After 9 wk, feed was offered as a TMR (Table 1). The TMR was formulated to contain equal amounts of forage NDF $(8 \pm 0.5 \%)$ on a DM basis. Grower intake was capped at $2.25 \mathrm{~kg} / \mathrm{d}$ of DM, and forage was offered ad libitum. Calves were limit-fed TMR to restrict the grower intake as stated, and additional forage was offered after $8 \mathrm{~h}$ if the entire TMR allotment was consumed on any given day.

Calves were housed individually in outside hutches from 7 to 9 wk and in a mechanically ventilated barn from 9 to 16 wk of age and bedded with shavings as necessary. At 11 and 15 wk of age, cannulated animals were moved into the metabolism barn at the Penn State dairy farm (mechanically ventilated tiestall barn) where total fecal collection occurred for $4 \mathrm{~d}$ and rumen sampling occurred over the last $24 \mathrm{~h}$ of each sampling period.

\section{Sample Collection and Analysis}

Initial BW, hip width, heart girth, and paunch girth were determined at $7 \mathrm{wk}$ of age and subsequently measured on a weekly basis until calves completed the study at 16 wk. Calves were fed daily at $0800 \mathrm{~h}$ and those $>9$ wk of age and consuming a TMR were checked $8 \mathrm{~h}$ later to determine whether the ration had been consumed and whether additional forage was needed. All feed offerings were recorded on a daily basis. Orts were collected on a weekly basis for calves from 7 to $9 \mathrm{wk}$ of age that consumed a component ration and those that were

Table 1. Nutrient and ingredient composition of feedstuffs and diets

\begin{tabular}{lcccc}
\hline Item $^{1}$ & $\begin{array}{c}\text { Alfalfa } \\
\text { haylage }\end{array}$ & $\begin{array}{c}\text { Corn } \\
\text { silage }\end{array}$ & $\begin{array}{c}\text { Grass } \\
\text { hay }\end{array}$ & $\begin{array}{c}\text { Texturized } \\
\text { grower }^{2}\end{array}$ \\
\hline Nutrient & & & & \\
DM (\%) & 39.6 & 42.3 & 89.5 & 89.6 \\
CP & 23.5 & 7.8 & 10.0 & 20.4 \\
ADF & 35.2 & 17.5 & 40.3 & 5.0 \\
NDF & 42.8 & 32.2 & 67.3 & 41.9 \\
Starch & 0.4 & 39.8 & 1.5 & 8.2 \\
Ash & 10.5 & 3.5 & 5.7 & 1.3 \\
Ca & 1.7 & 0.2 & 0.5 & 3.1 \\
P & 0.4 & 0.3 & 0.3 & \\
ME (Mcal/kg) & 2.3 & 2.8 & 2.1 & \\
TMR composition & & & & \\
Alfalfa haylage & 20.0 & 24.5 & & \\
Corn silage & & & & \\
Grass hay & 80.0 & 75.5 & 88.7 & \\
Texturized grower & & & \\
\hline
\end{tabular}

${ }_{1} \%$ of DM unless otherwise noted.

${ }^{2}$ Texturized grower (Ridley Inc., Lancaster, PA) with or without yeast had the same nutrient composition. Grower ingredient composition, as fed: cracked corn, $63.35 \%$; calf and heifer protein concentrate, $32.5 \%$; molasses with fat, $4 \%$; mold inhibitor, $0.15 \%$.

${ }^{3} \mathrm{TMR}$ was formulated to contain $7.6 \%$ forage NDF. Due to differing forage quality, forage NDF $=8 \pm 0.5 \%$ (alfalfa haylage $=8.6 \%$; corn silage $=7.9 \%$; grass hay $=7.6 \%$ ).

${ }^{4}$ Calculated according to the NRC $(2001)$ equation: $\mathrm{ME}=1.01 \times(0.04409 \times \mathrm{TDN})-0.45$.

${ }^{5}$ Alfalfa haylage TMR $=21.0 \% \mathrm{CP}, 20.3 \% \mathrm{NDF}, 33.6 \%$ starch, and $2.94 \mathrm{Mcal} / \mathrm{kg} \mathrm{ME}$; corn silage TMR $=$ $17.3 \% \mathrm{CP}, 19.0 \% \mathrm{NDF}, 41.4 \%$ starch, and $3.02 \mathrm{Mcal} / \mathrm{kg} \mathrm{ME}$; grass hay TMR $=19.2 \% \mathrm{CP}, 20.6 \% \mathrm{NDF}, 37.3 \%$ starch, and $2.99 \mathrm{Mcal} / \mathrm{kg} \mathrm{ME} \mathrm{(DM} \mathrm{basis).}$ 
not offered additional forage. Calves that consumed the entire TMR allotment within $8 \mathrm{~h}$ were offered additional forage and had their orts collected the following morning. Orts were used to calculate daily intake. Orts and weekly feedstuff samples were dried in a forced-air oven at $55^{\circ} \mathrm{C}$ for $48 \mathrm{~h}$ to determine DM (AOAC International, 2000), ground using a 1-mm screen in a Wiley mill (Arthur H. Thomas, Philadelphia, PA), and stored for further analysis.

Total fecal collection took place for 4 consecutive days during 11 and 15 wk. A subsample was collected for each day and composited for the collection period. Composited samples were dried in a forced-air oven at $55^{\circ} \mathrm{C}$ for $72 \mathrm{~h} \mathrm{(AOAC} \mathrm{International,} \mathrm{2000),} \mathrm{ground}$ using a 1-mm screen in a Wiley mill, and stored for further analysis.

Dried and ground orts, feedstuffs, and fecal samples were analyzed for DM (AOAC International, 2000), NDF and ADF (Van Soest et al., 1991), and starch (Hall, 2009). An Ankom200 fiber analyzer (Ankom Technology Corp., Fairport, NY) was used for NDF and ADF analysis. Heat-stable $\alpha$-amylase and sodium sulfite were used in the determination of NDF (Van Soest et al., 1991). Starch content was determined using a modified method of Hall (2009). Feedstuffs were further analyzed for CP, ash, Ca, and P by Cumberland Valley Analytical Services (Waynesboro, PA) according to their procedures (Cumberland Valley Analytical Services Inc., 2011). Metabolizable energy was estimated from TDN according to the NRC (2001) equation ME $=1.01 \times(0.04409 \times \mathrm{TDN})-0.45$.

Rumen fluid samples were collected during the last $24 \mathrm{~h}$ of each fecal collection period at $0,1,2,4,6,8$, 12, 16, 20, and $22 \mathrm{~h}$ postfeeding. A plastic hose with a metal suction strainer (Precision Machine Company Inc., Lincoln, NE) attached to one end and a 60-mL syringe attached to the other was inserted into the rumen via the cannula opening and used to draw the sample. Care was taken to ensure the ventral sac of the rumen was sampled each time, as the small size of the cannula inhibited our ability to accurately sample multiple locations within the rumen. Once a fluid sample was drawn, $\mathrm{pH}$ was tested immediately using a hand-held portable pH meter (model M90, Corning Inc., Corning, NY). A 5 -mL sample of rumen fluid was saved in a $15-\mathrm{mL}$ tube containing $1 \mathrm{~mL}$ of $0.6 \%$ 2-ethylbutyric acid and $1 \mathrm{~mL}$ of $25 \%$ metaphosphoric acid and stored at $-20^{\circ} \mathrm{C}$ until analyzed for VFA content (Yang and Varga, 1989).

Blood samples were collected weekly from the jugular vein into evacuated tubes containing sodium heparin (Vacutainer, Becton Dickinson, Franklin Lakes, NJ) and centrifuged at $4^{\circ} \mathrm{C}$ for $15 \mathrm{~min}$ at $1,500 \times g$. Plasma was collected and stored at $-20^{\circ} \mathrm{C}$ until analyzed for haptoglobin according to procedures outlined by Cooke and Arthington (2013). Haptoglobin was categorized as high or low based on the threshold of $50 \mu \mathrm{g} / \mathrm{mL}$ outlined by Gelsinger et al. (2016). Calves were monitored for health and assigned daily fecal scores of 1 through 5 ( 1 = firm to soft; $5=$ watery, mucus, bloody) according to a CalfTrack system outlined by Lesmeister and Heinrichs (2004). Daily fecal scores and general health observations were recorded by trained personnel.

\section{Statistical Analysis}

Statistical analyses were conducted in SAS (version 9.4, SAS Institute Inc., Cary, NC) using PROC MIXED. Average fecal score was evaluated using PROC GLIMMIX. The experimental design was a $2 \times 3$ factorial, and the experimental unit was calf because they were housed individually and measurements were taken and known for each individual. Initial and final BW, frame measurements, fecal score $>1$, and high haptoglobin were evaluated with the fixed effects of yeast, forage, and yeast $\times$ forage interaction and the random block effect of sex. Initial BW and frame measurements did not differ between groups and were therefore not included as covariates in further analyses.

Growth and intake variables were evaluated with an expanded model that included the repeated effect of age, the interaction between forage $\times$ age, and the random effects of calf and week of study. The interactions of yeast $x$ age and forage $x$ yeast $x$ age were evaluated but removed from the model because they were not significant $(P>0.1)$. Week of study was added as a random variable to account for minor forage and weather differences throughout the study. Bayesian information criterion was reduced when the random effect of week of study was added to the model. A first-order autoregressive covariance matrix was applied as determined by Akaike's information criterion. Average fecal score was evaluated with the same model as growth and intake variables, but PROC GLIMMIX was used and a Poisson distribution was applied.

Only male calves were used for the evaluation of digestibility, rumen $\mathrm{pH}$, and VFA; thus, the random effect of sex was removed when evaluating these variables. Maximum and minimum $\mathrm{pH}$, along with digestibility variables, were evaluated with the fixed effects of yeast, forage, the repeated effect of age, the interaction effects of yeast $\times$ forage and yeast $\times$ forage $\times$ age, and the random effects of calf and week of study. The interaction effects of forage $\times$ age and yeast $\times$ age were evaluated but excluded from the model because they were not significant. Mean rumen $\mathrm{pH}$ and VFA variables were evaluated using the same model but expanded to 
include time and its interactions. Spatial power covariance matrix was applied in the analysis of mean rumen $\mathrm{pH}$ and VFA variables as a result of unevenly spaced sampling intervals (Moser, 2004).

The slice option within SAS was used when appropriate to determine differences between forages at each age and between ages within each forage. KenwardRoger approximation was used to determine degrees of freedom for all procedures. Data are reported as least squares means along with standard error. Comparisons were made with the Tukey adjustment. Significant differences were declared at $P \leq 0.05$ and tendency at 0.05 $<P \leq 0.10$.

\section{RESULTS AND DISCUSSION}

\section{Diets}

Nutrient composition of feedstuffs and ingredient composition of TMR are presented in Table 1. Calves were offered their assigned texturized grower, and Y $(0.88 \mathrm{~g} / \mathrm{kg}$ of $\mathrm{DM})$ or $\mathrm{NY}$, and forage in component fashion from 7 to 9 wk of age. Calves were offered TMR from 9 to $16 \mathrm{wk}$ of age. For the duration of the study, grower intake was limited to $2.25 \mathrm{~kg} / \mathrm{d}$ of DM, and forage was offered ad libitum in an attempt to gauge how much forage calves at this age were able to consume and its effects on growth, digestibility, and ruminal fermentation. Nutrient composition of the texturized grower did not vary between Y and NY. However, as expected, nutrient compositions of $\mathrm{AH}, \mathrm{CS}$, and $\mathrm{GH}$ were quite different from one another, especially in regards to $\mathrm{CP}, \mathrm{NDF}$, and starch content. The grass hay was first cutting, primarily orchardgrass, and sourced from central Pennsylvania. Due to the effects of forage NDF on intake, TMR were formulated to contain similar levels of forage NDF $(8 \pm 0.5 \%$, DM basis $)$ to minimize its effect on intake (Allen, 2000). However, as a result of balancing for forage NDF, TMR did differ in $\mathrm{CP}$ and starch content, which we discuss later.

\section{Intake}

There were no effects of yeast or yeast $x$ forage interaction for any of the observed intake variables or feed efficiency (Table 2). These results agree with Quigley et al. (1992) and Magalhães et al. (2008), but others have shown yeast to increase intake in younger calves (Lesmeister et al., 2004; Galvão et al., 2005). Despite increasing intake, only Galvão et al. (2005) showed an improvement in feed efficiency, and the improvement was only in the preweaning period. It is also worth noting that none of the studies investigated calves through
16 wk of age, but Galvão et al. (2005) and Quigley et al. (1992) were most similar to the present study, as they weaned calves at $6 \mathrm{wk}$ of age and studied them through 12 wk of age. A review by Alugongo et al. (2017) found that addition of yeast in many studies only increased DMI in calves that were under stress. In the current study, calves were generally healthy and without stress, as observed by low fecal scores and haptoglobin values (Table 3), which may partially explain the lack of effects by yeast.

The forage offered had an effect on all intake variables. Calves assigned GH had reduced DMI compared with those assigned $\mathrm{AH}$ and $\mathrm{CS}(2.68,2.93$, and 2.90 $\mathrm{kg} / \mathrm{d}$ for $\mathrm{GH}, \mathrm{AH}$, and $\mathrm{CS} ; P=0.04$ and 0.08 , respectively). The TMR were formulated to contain similar levels of forage NDF. As a result, the reduction in DMI seen in those offered GH is likely due to chemical characteristics of grass hay, which cause it to pass more slowly from the rumen (Waghorn et al., 1989; Allen, 1996). Dry matter intake increased each week of the study, regardless of forage, and there was an interaction between forage and age. Figure 1A shows how DMI increased with animal age, and those consuming $\mathrm{AH}$ increased at a much greater rate. Calves fed $\mathrm{AH}$ had less DMI from 8 to 10 wk of age (2.08 vs. 2.23 vs. 2.17 $\mathrm{kg} / \mathrm{d}$, respectively), but had the greatest DMI (3.64 vs. 3.37 vs. $3.08 \mathrm{~kg} / \mathrm{d}$ respectively) from 13 to $16 \mathrm{wk}$ of age compared with those fed CS or GH. Similar results were observed for DMI as percent of BW (Figure 1B), except GH was not different from CS and only tended to be less than $\mathrm{AH}$. We found an interaction between forage and age, where DMI as percent of BW increased from wk 10 to 11 and decreased from wk 11 to 16 for calves fed CS, whereas DMI as percent of BW increased from wk 10 to 16 for calves fed AH. However, DMI as percent of BW did not change with age for calves fed $\mathrm{GH}$.

Grower intake tended to be different among the groups; GH consumed the greatest amount and $\mathrm{AH}$ consumed the least. In the first 2 wk of the study (7-9 wk of age), forage and grower were offered as separate components, and $\mathrm{AH}$ calves consumed much higher levels of forage, and subsequently much lower levels of grower. Hill et al. $(2008,2009 b)$ showed that starter intake decreased with increasing levels of roughage (grass hay and cottonseed hulls), but the diets were offered as a TMR. Conversely, Castells et al. (2012) offered calves various forages, free choice, from 2 to 10 wk of age and observed that oat hay, barley straw, and triticale silage increased starter intake compared with a control group that was not fed forage, but other forages (alfalfa hay, ryegrass hay, and corn silage) did not affect starter intake. However, forage intake as percent 
Table 2. Intake and efficiency of weaned dairy calves offered TMR containing alfalfa haylage (AH), corn silage (CS), or grass hay (GH) and grower with or without yeast

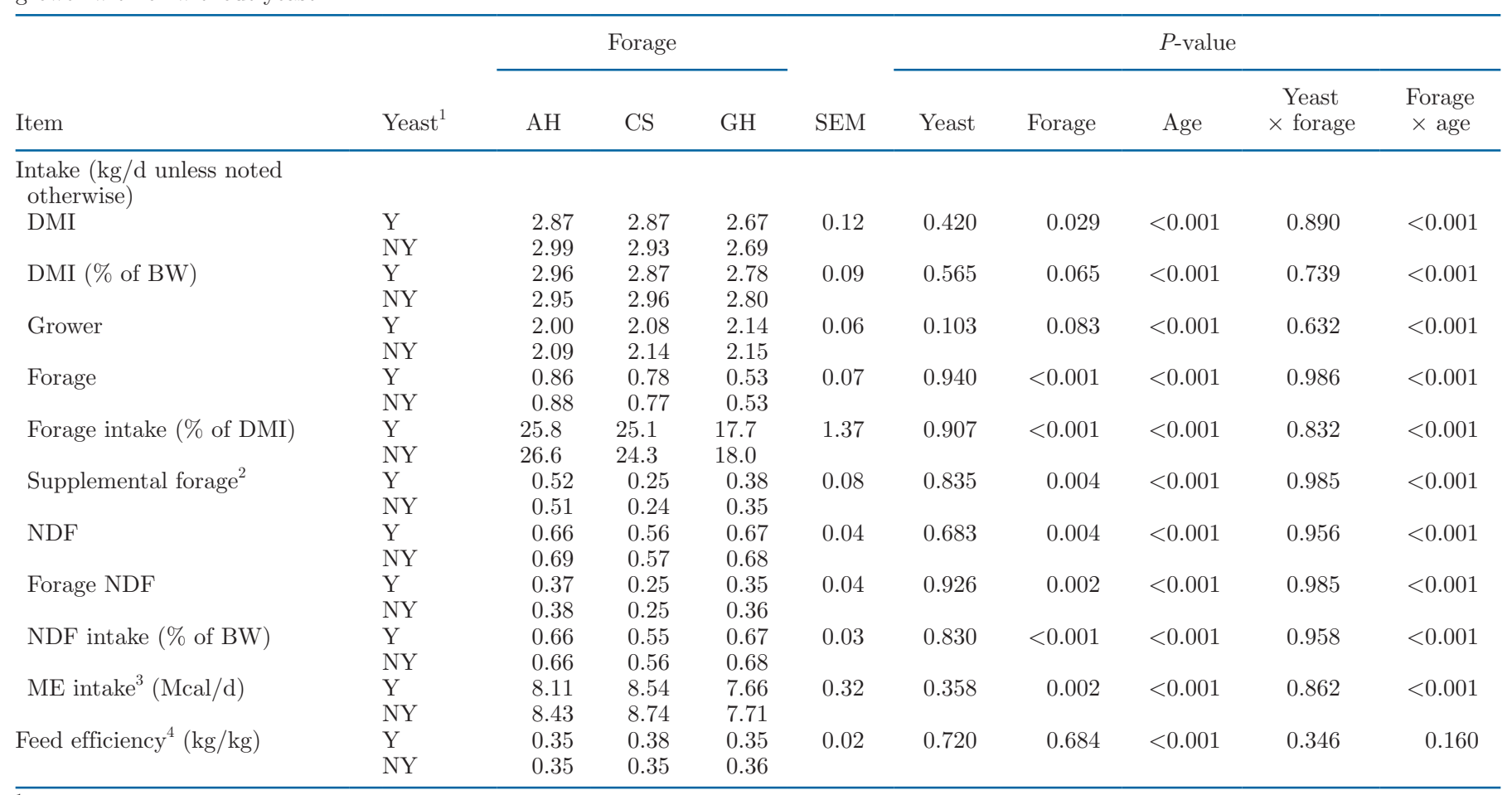

${ }^{1} \mathrm{Y}=$ yeast inclusion; $\mathrm{NY}=$ no yeast inclusion.

${ }^{2}$ Forage consumed after total TMR allotment had been consumed.

${ }^{3} \mathrm{ME}$ intake was calculated by multiplying ME (Mcal $/ \mathrm{kg}$ ) content of forage and grower by the DM $(\mathrm{kg})$ consumed of each.

${ }^{4}$ Feed efficiency was calculated by dividing ADG by DMI.

of DMI in the study by Castells et al. (2012) was much lower for calves at 10 wk of age than what was observed in the present study for $\mathrm{AH}$ in wk 8 and 9 (5.7\% vs. $11.1 \%$, respectively). It is also worth noting that Hill et al. $(2008,2009 b)$ offered calves a texturized starter, whereas Castells et al. (2012) offered calves a pelleted starter. Calves offered forage with texturized starters have been shown to have reduced DMI, and calves of- fered forage with a pelleted or ground starter have been shown to have increased DMI (Imani et al., 2017).

The amount of forage included in the TMR containing $\mathrm{AH}$ and $\mathrm{CS}$ was much greater than $\mathrm{GH}(20$, 24.5 , and $11.3 \%$ of $\mathrm{DM}$ for $\mathrm{AH}, \mathrm{CS}$, and $\mathrm{GH}$ ) due to balancing the diets for forage NDF. This resulted in calves on $\mathrm{AH}$ and $\mathrm{CS}$ consuming more forage than $\mathrm{GH}$, but AH was only numerically more than CS. This also

Table 3. Fecal score and high haptoglobin incidence of weaned dairy calves offered TMR containing alfalfa haylage (AH), corn silage (CS), or grass hay $(\mathrm{GH})$ and grower with or without yeast

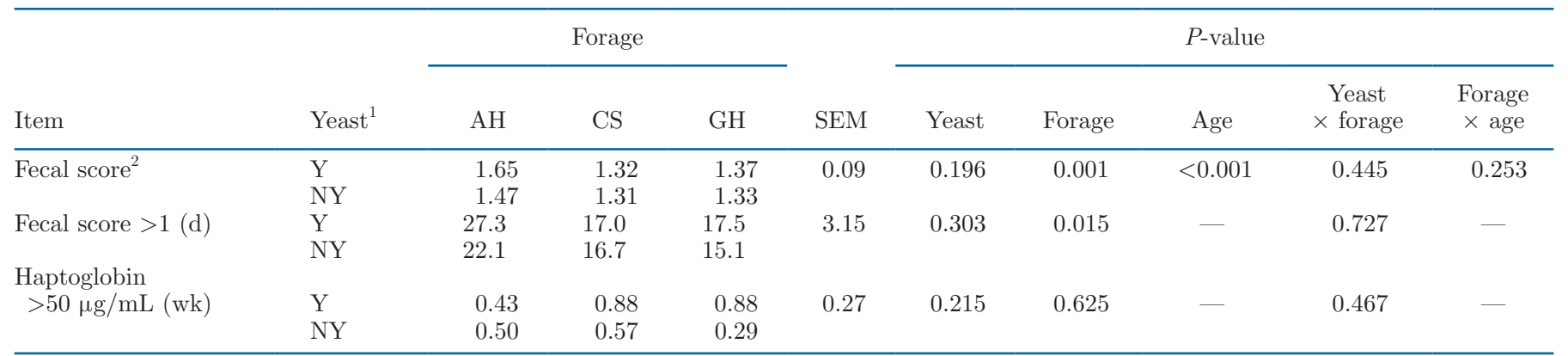

${ }^{1} \mathrm{Y}=$ yeast inclusion; $\mathrm{NY}=$ no yeast inclusion.

${ }^{2}$ Calves were assigned fecal scores (1-5; firm to watery/bloody) daily according to the CalfTrack system outlined by Lesmeister and Heinrichs (2004). 

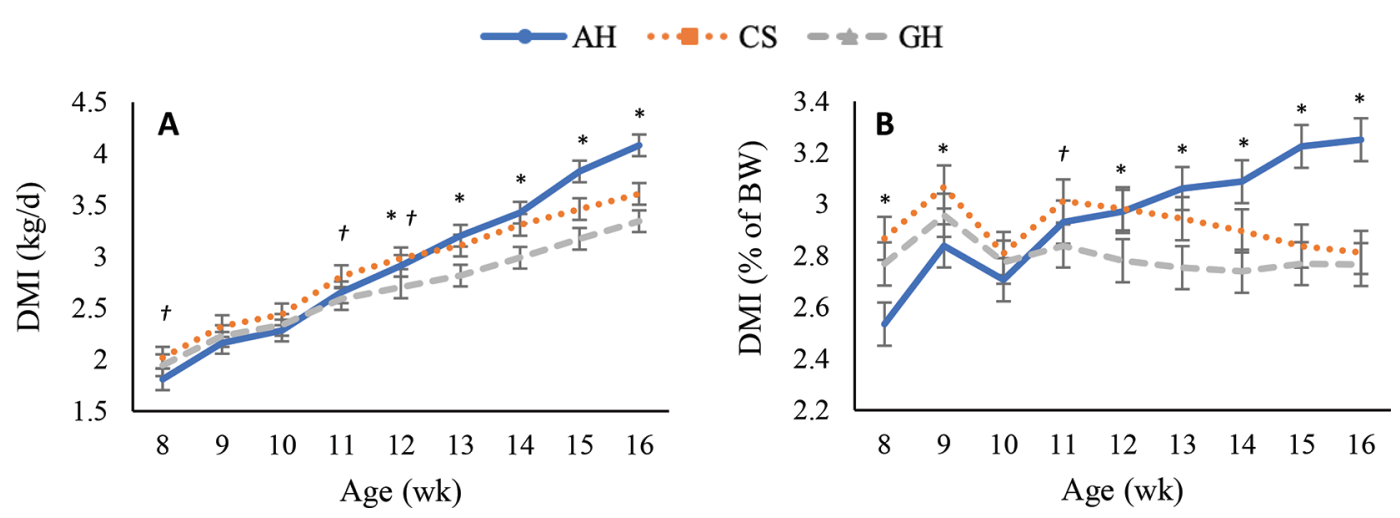

Figure 1. (A) Weekly DMI of weaned dairy calves. *Signifies differences between groups at that age; $P \leq 0.05(12$ wk CS $>$ GH; 13 and $14 \mathrm{wk} \mathrm{CS}$ and $\mathrm{AH}>\mathrm{GH} ; 15 \mathrm{wk}$ and $16 \mathrm{wk} \mathrm{AH}>\mathrm{CS}$ and $\mathrm{GH} ; \mathrm{CS}>\mathrm{GH})$. $\dagger$ Signifies trends between groups at that age; $0.05<P \leq 0.1(8$ wk $\mathrm{CS}>\mathrm{AH} ; 11 \mathrm{wk} \mathrm{CS}>\mathrm{GH} ; 12 \mathrm{wk} \mathrm{AH}>\mathrm{GH}$ ). (B) Weekly DMI as percent of BW for weaned dairy calves. * Signifies differences between groups at that age; $P \leq 0.05$ ( 8 wk CS and GH $>$ AH; 9 wk $\mathrm{CS}>\mathrm{AH} ; 12$ and 13 wk AH and $\mathrm{CS}>\mathrm{GH} ; 14,15$, and 16 wk $\mathrm{AH}>\mathrm{CS}$ and $\mathrm{GH}$ ). †Signifies trends between groups at that age; $0.05<P \leq 0.1$ (9 wk $\mathrm{CS}>\mathrm{GH})$. AH = alfalfa haylage; $\mathrm{CS}=$ corn silage; GH $=$ grass hay. Error bars represent $\pm \mathrm{SE}$.

likely played a role in the observed differences in grower intake due to the fact calves fed $\mathrm{AH}$ and $\mathrm{CS}$ would need to consume more total DM to consume the grower amount capped at $2.25 \mathrm{~kg}$ of DM. As a result, calves offered $\mathrm{AH}$ and $\mathrm{CS}$ were likely more limited by gut fill early in the study, which led to the tendency for decreased grower intake.

Figure 2A illustrates how forage intake changed with age. There were increases in forage intake for calves throughout the study, but those on $\mathrm{AH}$ had the greatest increase (1.63 vs. 1.25 vs. $1.01 \mathrm{~kg} / \mathrm{d}$ increase in forage intake from 8-16 wk for $\mathrm{AH}, \mathrm{CS}$, and $\mathrm{GH}$, respectively). At $8 \mathrm{wk}$, forage intake was similar between groups, but between wk 10 and 16, calves fed $\mathrm{AH}$ and CS had greater forage intake than calves fed GH. However, by wk 15 and 16, calves fed AH consumed more forage than calves fed CS and GH, and calves fed CS consumed more forage than those fed GH. The reason calves offered CS had increased forage intake compared with those offered GH is likely due to being offered increased levels of forage in their TMR to balance the TMR for forage NDF. The reason calves offered AH had such an increase in forage intake is likely tied to the highly digestible nature of $\mathrm{AH}$ allowing for increased passage rate and increased intakes (Allen, 2000).

Figure $2 \mathrm{~B}$ demonstrates that calves offered $\mathrm{AH}$ and CS did not consume their entire TMR allotment until an older age compared with those offered GH. Calves consuming $\mathrm{CS}$ and $\mathrm{AH}$ did not increase forage intake as percent of DMI from 10 to 12 wk and 10 to 11 wk, respectively. However, they increased each week thereafter. Calves offered GH increased forage intake as percent of DMI each week. This was likely due to the increased levels of forage provided in the $\mathrm{AH}$ and CS TMR, which would have increased the necessary DMI for the calves to consume the entire TMR allotment. This is further shown in the evaluation of supplemental forage intake (Figure 2C). Calves offered $\mathrm{AH}$ consumed the most supplemental forage, and CS consumed the least. However, supplemental forage intake of $\mathrm{AH}$ was only greater than $\mathrm{CS}$, and GH was not different from either AH or CS.

Figure 2C illustrates the changes in supplemental forage intake as the calves aged. Calves receiving CS did not consume appreciable amounts of supplemental forage until $13 \mathrm{wk}$, and $\mathrm{GH}$ and $\mathrm{AH}$ started consuming more supplemental forage at 11 and $12 \mathrm{wk}$, respectively. By 13 wk, calves fed AH had an almost 290\% increased intake of supplemental forage compared with those fed CS. By wk 15, AH calves had almost 200 and $150 \%$ greater supplemental forage intake than either CS or GH, respectively. Calves fed GH consumed more supplemental forage than calves fed CS overall, but only tended to consume more supplemental forage wk 15 and 16. The increased consumption of legumes compared with perennial grasses is commonly observed (Colburn et al., 1968; Castells et al., 2012, 2013), likely due to decreased rumen retention times for legumes (Allen, 2000). However, the low levels of supplemental forage intake of CS were unexpected because CS contains less $\mathrm{NDF}$ than $\mathrm{AH}$ and $\mathrm{GH}$, and NDF content is highly correlated with intake (Van Soest, 1965). Furthermore, similar DMI has been observed between cows fed diets comparing AH and CS (Broderick, 1985; Dhiman and Satter, 1997).

The reduced supplemental forage intake of calves offered CS compared with those fed AH or GH resulted in less intake of NDF and forage NDF. These results suggested that regulation of intake was different for calves offered different forages. It appears that NDF 
consumption was the primary regulator of intake for calves offered GH, but ME intake was the primary regulator of intake for calves offered CS. Hill et al. (2010) evaluated the effect of percent of NDF in the diet from roughage on intake and reported that DMI did not change until diets contained $>3 \%$ NDF from roughage, at which point DMI declined. In the cur-
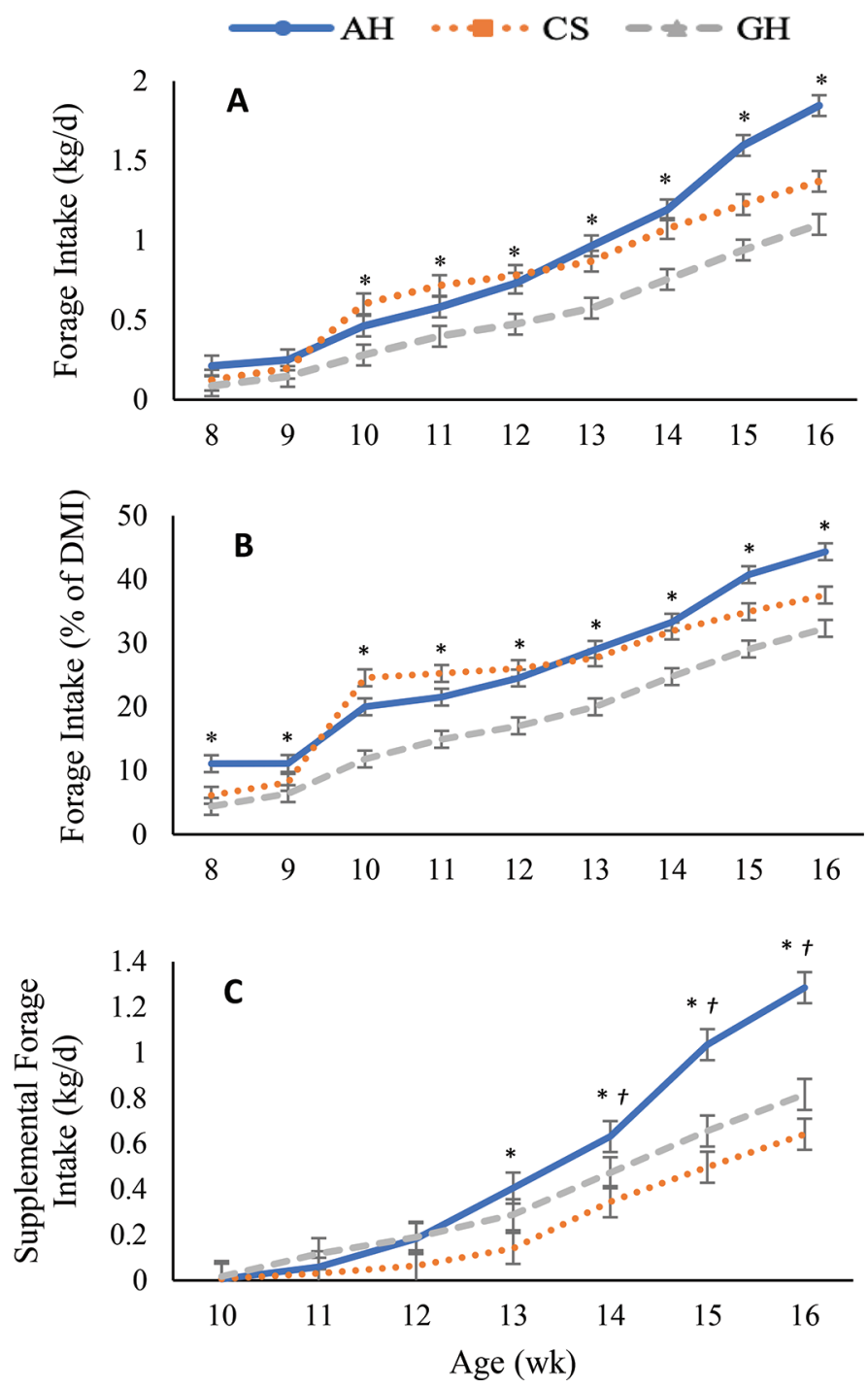

Figure 2. (A) Weekly forage intake of weaned dairy calves. *Signifies differences between groups at that age; $P \leq 0.05$ (10, 11, 12, $13,14,15$, and 16 wk $\mathrm{AH}$ and $\mathrm{CS}>\mathrm{GH} ; 15$ and 16 wk $\mathrm{AH}>\mathrm{CS}$ ). (B) Weekly forage intake (\% of DM) of weaned dairy calves. *Signifies differences between groups at that age; $P \leq 0.05$ ( 8 wk AH $>$ CS and $\mathrm{GH} ; 9$ wk $\mathrm{AH}>\mathrm{GH} ; 10$ and 11 wk $\mathrm{CS}>\overline{\mathrm{A}} \mathrm{H}$ and $\mathrm{GH} ; \mathrm{AH}>\mathrm{GH} ; 12$, 13, and 14 wk $\mathrm{AH}$ and $\mathrm{CS}>\mathrm{GH} ; 15$ and $16 \mathrm{wk} \mathrm{AH}>\mathrm{CS}$ and GH; CS $>\mathrm{GH}$ ). (C) Weekly supplemental forage intake of weaned dairy calves. *Signifies differences between groups at that age; $P \leq 0.05$ (13 wk AH $>\mathrm{CS} ; 14 \mathrm{wk} \mathrm{AH}>\mathrm{CS} ; 15$ and $16 \mathrm{wk} \mathrm{AH}>\mathrm{CS}$ and GH). †Signifies trends between groups at that age; $0.05<P<0.1$ (14 wk AH $>$ GH; 15 and 16 wk $\mathrm{GH}>\mathrm{CS}) . \mathrm{AH}=$ alfalfa haylage; $\mathrm{CS}=$ corn silage; $\mathrm{GH}$ $=$ grass hay. Error bars represent $\pm \mathrm{SE}$. rent study we evaluated NDF intake as percent of BW because the diets were balanced to contain similar $\%$ NDF from forage.

Figure 3A shows NDF intake as percent of BW as calves aged. Calves consuming $\mathrm{AH}$ and $\mathrm{GH}$ had the same NDF intake as percent of BW, and it increased each week until wk 16 , when it reached $0.89 \%$. This value appeared to be approaching the $1 \% \mathrm{NDF}$ intake as percent of BW observed by Hoffman et al. (2008), and suggests that calves consuming $\mathrm{AH}$ and $\mathrm{GH}$ had their intake limited by gut fill. It should be noted that the animals evaluated by Hoffman et al. (2008) were around 4 mo of age at the initiation of that study. Further studies should be conducted following calves to 24 to $28 \mathrm{wk}$ of age to determine whether a similar cap to $\mathrm{NDF}$ intake as percent of $\mathrm{BW}$ is observed.

In contrast to calves offered $\mathrm{AH}$ or $\mathrm{GH}$, calves offered CS increased NDF intake as percent of BW until $11 \mathrm{wk}$, at which point there were no further increases ( 0.58 vs. $0.60 \%$ for 11 vs. 16 wk of age). However, calves consuming CS had the greatest ME intake, which could indicate that intake of these calves was limited by energy (Allen et al., 2009) as opposed to NDF. Calves on GH consumed the least ME. Figure 3B shows that calves on AH consumed less ME than CS calves from 8 to 11 wk but the same amount of ME from 12 to $16 \mathrm{wk}$. These results reinforce the idea that animals on GH primarily had their intake limited by gut fill, and energy status likely had a greater effect for those offered CS. Interestingly, calves on $\mathrm{AH}$ had the same NDF intake as percent of $\mathrm{BW}$ as $\mathrm{GH}$ and the same ME intake as CS at the end of the study. This appeared to be the result of higher levels of supplemental forage intake by calves offered $\mathrm{AH}$, which allowed them to hit what appeared to be the controlling limits of energy and NDF intake observed in this study simultaneously. Feed efficiency did not differ between the groups, though it decreased as the animals aged, as expected.

\section{Growth}

There were no effects of yeast or the interaction of yeast $\times$ forage on any of the measured growth variables (Table 4). The effect of yeast on ADG is inconsistent, but generally those that observed a yeast effect on DMI saw a subsequent effect on ADG. Galvão et al. (2005) and Lesmeister et al. (2004) observed that yeast increased ADG. Interestingly, after weaning, the difference in ADG observed by Galvão et al. (2005) was no longer significant despite an increase in DMI that maintained postweaning. In a smaller study observing calves from birth to $13 \mathrm{wk}$ of age, Panda et al. (1995) found yeast increased ADG despite only numerical gains to DMI. Conversely, Quigley et al. (1992) and 


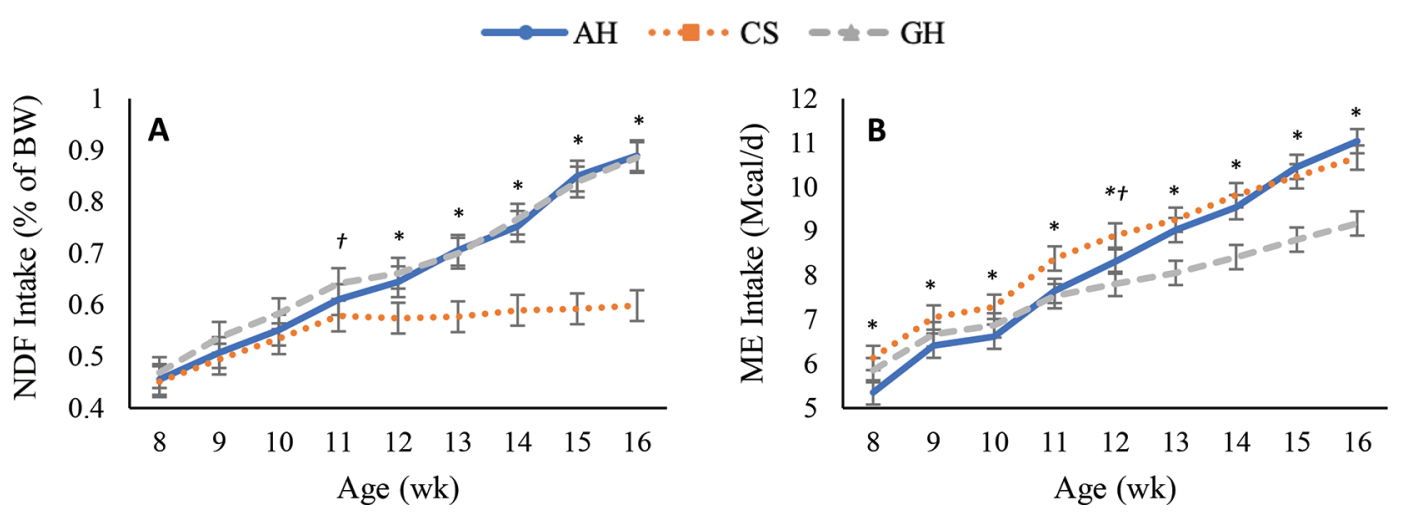

Figure 3. (A) Weekly NDF intake (\% of BW) of weaned dairy calves. *Signifies differences between groups at that age; $P \leq 0.05(12,13,14$, 15, and 16 wk AH and GH $>$ CS). †Signifies trends between groups at that age; $0.05<P \leq 0.1$ (11 wk GH $>$ CS). (B) Weekly ME intake of weaned dairy calves. *Signifies differences between groups at that age; $P \leq 0.05(8,9$, and 10 wk CS $>$ AH; 11 wk CS $>$ AH and GH; 12 wk CS $>\mathrm{GH} ; 13,14,15$, and $16 \mathrm{wk} \mathrm{AH}$ and $\mathrm{CS}>\mathrm{GH})$. †Signifies trends between groups at that age; $0.05<P \leq 0.1(12 \mathrm{wk} \mathrm{CS}>\mathrm{AH} ; \mathrm{AH}>\mathrm{GH})$. $\mathrm{AH}=$ alfalfa haylage; $\mathrm{CS}=$ corn silage; $\mathrm{GH}=$ grass hay. Error bars represent $\pm \mathrm{SE}$.

Magalhães et al. (2008) did not see any effect of yeast on ADG in calves raised from birth to 10 or 12 wk of age, respectively.

Initial BW, hip width, heart girth, and paunch girth, as measured at 7 wk of age, were not different between the different forage groups. However, final BW tended to be less for calves fed GH versus CS, and those fed AH had similar final BW to both. Despite slight differences in final BW, if calves in this study were put on a growth plan to gain $850 \mathrm{~g} / \mathrm{d}$ from 16 wk to $10 \mathrm{mo}$, and then $1 \mathrm{~kg} / \mathrm{d}$ from 10 mo to calving, they would meet desired growth goals of $55 \%$ mature BW at breeding (13 mo) and 95\% mature BW at calving (22 mo; mature BW at Penn State dairy is $680 \mathrm{~kg}$ ). It should be noted that this is one specific growth plan and is not intended to be presented as one size fits all. Calves under different conditions with different growth challenges or goals may require a different growth plan.

Table 4. Growth of weaned dairy calves offered TMR containing alfalfa haylage (AH), corn silage (CS), or grass hay (GH) and grower with or without yeast

\begin{tabular}{|c|c|c|c|c|c|c|c|c|c|c|}
\hline Item & Yeast $^{1}$ & \multicolumn{3}{|c|}{ Forage } & SEM & \multicolumn{5}{|c|}{$P$-value } \\
\hline \multirow[t]{2}{*}{ Initial BW (kg) } & $\mathrm{Y}$ & 63.9 & 65.2 & 64.9 & 3.03 & 0.754 & 0.924 & - & 0.778 & - \\
\hline & NY & 66.9 & 65.5 & 63.8 & & & & & & \\
\hline Final BW (kg) & $\mathrm{Y}$ & 123.5 & 129.0 & 120.8 & 3.30 & 0.599 & 0.088 & - & 0.679 & - \\
\hline $\mathrm{ADG}(\mathrm{kg} / \mathrm{d})$ & NY & 0.97 & 0.98 & 0.92 & & & & & & \\
\hline \multirow{2}{*}{$\mathrm{EBWG}^{2}(\mathrm{~kg} / \mathrm{d})$} & $\mathrm{Y}$ & 0.82 & 0.92 & 0.75 & 0.04 & 0.775 & $<0.001$ & $<0.001$ & 0.338 & 0.011 \\
\hline & NY & 0.84 & 0.88 & 0.79 & & & & & & \\
\hline \multicolumn{11}{|l|}{ Frame } \\
\hline \multirow[t]{2}{*}{ Initial hip width $(\mathrm{cm})$} & $\mathrm{Y}$ & 20.0 & 19.9 & 20.3 & 0.34 & 0.753 & 0.930 & - & 0.162 & - \\
\hline & NY & 20.2 & 20.4 & 19.8 & & & & & & \\
\hline Final hip width $(\mathrm{cm})$ & $\mathrm{Y}$ & 25.9 & 26.0 & 26.0 & 0.40 & 0.278 & 0.341 & - & 0.302 & - \\
\hline \multirow[t]{2}{*}{ Initial paunch girth $(\mathrm{cm})$} & $\mathrm{Y}$ & 99.4 & 101.9 & 100.8 & 2.65 & 0.158 & 0.667 & - & 0.763 & - \\
\hline & NY & 103.5 & 104.1 & 101.8 & & & & & & \\
\hline \multirow[t]{2}{*}{ Final paunch girth $(\mathrm{cm})$} & $\mathrm{Y}$ & 136.1 & 134.4 & 134.9 & 2.10 & 0.650 & 0.816 & - & 0.875 & - \\
\hline & NY & 135.9 & 135.1 & 136.7 & & & & & & \\
\hline
\end{tabular}

${ }^{1} \mathrm{Y}=$ yeast inclusion; $\mathrm{NY}=$ no yeast inclusion.

${ }^{2} \mathrm{EBWG}=$ empty body weight gain; calculated according to equations given by Jahn and Chandler (1976). 
Similar to final BW, calves offered CS tended to have the greatest final heart girth, which was expected based on their increased final $\mathrm{BW}$ and the high correlation between BW and heart girth (Heinrichs et al., 1992; Dingwell et al., 2006). There were no differences in final hip width or paunch girth, and animals were on track to have very high structural growth for their age based on population studies (Heinrichs and Losinger, 1998).

The tendency for calves on CS to have greater final BW can be attributed to their increased ADG. Calves on $\mathrm{GH}$ had significantly less ADG, and those on $\mathrm{AH}$ were not different from either. The differences in weight gain align with observed differences in ME intake between the 3 forage groups. The evaluation of empty BW gain (EBWG), using the equation published by Jahn and Chandler (1976), produced similar results to ADG, but CS was increased compared with both $\mathrm{AH}$ and GH. The difference in EBWG between $\mathrm{AH}$ and CS appeared to be the result of increased gut fill for calves on AH. This was understood because EBWG was 13 and $10 \%$ lower than ADG for $\mathrm{AH}$ and CS, respectively. It was expected for CS to have the least gut fill because the equations used by Jahn and Chandler (1976) calculate gut fill based primarily on dietary CP and $\mathrm{ADF}$ content. The differences in gut fill along with similar levels of DMI observed between calves consuming $\mathrm{AH}$ and $\mathrm{CS}$ were thought to produce differences in paunch girth. The reasons for a lack of effect on paunch girth were not readily apparent. Zanton and Heinrichs (2007) saw similarly interesting results when they limitfed heifers either a high-forage or high-concentrate diet, but observed paunch growth to be increased for heifers fed high-concentrate. Those authors speculate that this may be due to increased visceral fat for heifers fed highconcentrate diets.

Average daily gain was fairly consistent across all ages with the exception of 10 wk of age. At 10 wk of age, there was an increase in ADG for calves on each forage, and the increase was especially pronounced in those fed CS (92 vs. 65 vs. $42 \%$ increase in ADG from 9-10 wk of age for CS, GH, and AH, respectively). This was largely in part due to calves being offered TMR at 9 wk of age. Forage consumption greatly increased when calves started their TMR, which would have led to greater gut fill leading up to being weighed at $10 \mathrm{wk}$ of age. Due to the spike in ADG at 10 wk of age, we re-analyzed ADG specifically from 11 to $16 \mathrm{wk}$. Calves fed $\mathrm{AH}$ had increased ADG from 955 to $970 \mathrm{~g} / \mathrm{d}$, and calves fed CS and GH decreased ADG from 1,000 to $963 \mathrm{~g} / \mathrm{d}$ and 900 to $850 \mathrm{~g} / \mathrm{d}$, respectively, when wk 8 to 10 were removed. At 16 wk of age, calves on $\mathrm{AH}$ grew $970 \mathrm{~g} / \mathrm{d}$ when eating $44.4 \%$ of their DM as forage, calves on CS grew $923 \mathrm{~g} / \mathrm{d}$ when eating $37.6 \%$ of their
DM as forage, and calves on GH grew $909 \mathrm{~g} / \mathrm{d}$ when eating $32.3 \%$ of their DM as forage. There is concern about how much forage recently weaned dairy heifers should be offered due to lack of size and the potential inability to consume enough energy to accomplish desired growth rates (Heinrichs, 1996). The amount of forage that these animals were able to consume and still accomplish adequate growth rates presents an opportunity to feed weaned calves higher levels of forage at younger ages.

\section{Fecal Score and Haptoglobin}

In the present study, we found no effect of yeast on any of the health parameters evaluated. A review by Alugongo et al. (2017) found 8 studies that showed reductions to diarrhea through either reduced incidence or improved fecal scores, but only 3 studies that showed no reduction to diarrhea in response to yeast supplementation. However, the studies included in the review focused primarily on the preweaning stage. The current study focused solely on weaned calves that entered the study at 7 wk of age after weaning at 6 wk of age. This could explain why we did not observe any effects of yeast on the health parameters that were evaluated. There is also some debate around the efficacy of yeast products when animals are experiencing stress. Chaucheyras-Durand et al. (2008) contended that yeast products are particularly useful in periods of dietary change and stress, while Quigley et al. (1992) suggested that disease challenges in the calves they were studying covered up the potential effects of yeast. Calves in the current study were generally healthy and did not experience any events that would have caused undue stress.

Calves assigned to AH had increased fecal scores and days with a fecal score $>1$ compared with calves assigned either CS or GH. Calves on AH were consuming increased levels of soluble protein. The AH used in this study contained $62.5 \%$ of the $\mathrm{CP}$ as soluble protein. This high level of soluble protein intake may be responsible for the increase in observed fecal scores. Increased soluble protein intake would lead to increased levels of ammonia production, likely increasing demand on the liver to produce urea to be excreted in the urine (Huntington and Archibeque, 2000). We expect that this increased demand to excrete urea in the urine was accompanied by an increase in water intake, which would be expected to have an effect on fecal consistency. Furthermore, the increased DMI of calves offered AH resulted in increased rumen undegradable protein due to increased passage rates, which would be expected to affect fecal consistency. We also observed an age effect on fecal score that showed fecal scores improved as 
the calves aged. In the evaluation of haptoglobin, there were no effects of forage on weeks with haptoglobin $>50 \mu \mathrm{g} / \mathrm{mL}$. In general, based on the low fecal scores and low incidence of high haptoglobin, animals in the current study were in good health regardless of yeast inclusion or forage assignment.

\section{Digestibility}

There were no effects of yeast or the interaction of yeast $x$ forage on nutrient digestibility in the present study (Table 5). In an in vitro study, Callaway and Martin (1997) found that yeast culture stimulated the growth of fibrolytic bacteria. Furthermore, in a metaanalysis evaluating lactating cow response to yeast products, Robinson and Erasmus (2009) stated that positive effects of yeast supplementation may be the result of yeast-stimulating rumen microbes that increase fermentability of fiber. In a study evaluating Holstein heifers near $17 \mathrm{mo}$ of age, averaging $432 \mathrm{~kg}$ of BW, yeast dose was found to have a quadratic effect on fiber digestibility, with yeast culture inclusion of 30 $\mathrm{g} / \mathrm{d}$ exhibiting the greatest NDF and ADF digestibility (Lascano et al., 2012). The lack of a fiber-digestibility response to yeast inclusion in the current study could be the result of the TMR having a low level of NDF (average $20 \%$ of DM basis). Lascano et al. (2012) fed diets at $38 \% \mathrm{NDF}$, and the general recommendation for lactating cows is 25 to $33 \% \mathrm{NDF}$ (NRC, 2001). We are unable to make comparisons to similar aged animals consuming similar diets due to a lack of data evaluating the effect of yeast on digestibility in calves from birth through 16 wk.

Dry matter digestibility was not affected by forage, but it decreased with age from $73.5 \%$ at 11 wk to $71.2 \%$ at 15 wk. A potential reason for the observed decrease was that intake greatly increased in these animals from 11 to $15 \mathrm{wk}$ of age. It is well accepted that increased intake leads to increased passage rate (Van Soest, 1982), which may subsequently decrease digestibility. However, the rumen of a developing calf from 2 to 4 mo of age would increase in volume at the same time as the intake increases, which may mitigate the effects of increased intake on passage rate. There is a lack of information on how passage rate changes with age in recently weaned calves. A more likely reason for the reduction in DM digestibility was that calves were consuming rations containing increased levels of forage at $15 \mathrm{wk}$ of age (forage intake as percent of DM; 20.6 and $38.1 \%$ at 11 and $15 \mathrm{wk}$ of age, respectively). The increase in forage intake as percent of DM lead to an increase in consumption of NDF, which decreases DM digestibility (Pino et al., 2018). There were no effects of age on the digestibility of other nutrients.

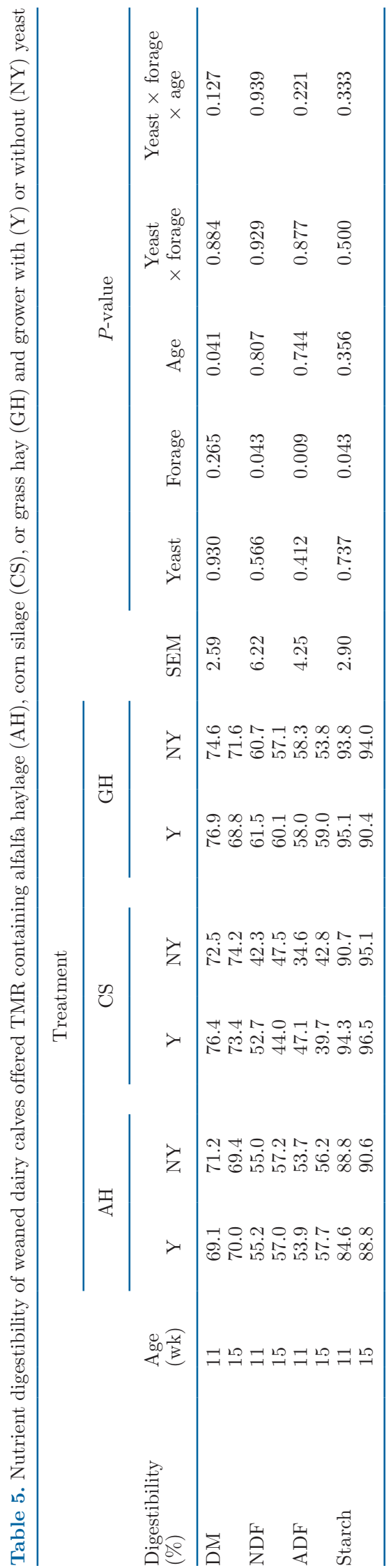


The effects of forage on NDF and ADF digestibility were similar in that calves on GH had the greatest NDF and ADF digestibility, and calves on CS exhibited the least NDF and ADF digestibility. It is likely that differences in NDF composition between the forages played a role in these observations. Furthermore, calves consuming CS also had reduced intakes of NDF, and this likely played a role in the reduced NDF and ADF digestibility observed for this group. It has been shown by other studies that NDF digestibility increases with increased NDF inclusion in diets for heifers at 12 to 16 mo of age (Zanton and Heinrichs, 2009) and those at 12 wk of age (Dennis et al., 2018). The values for NDF digestibility observed in the current study are comparable with those obtained by Castells et al. (2012) for calves at 9 wk of age. Castells et al. (2012) also reported numerically lower NDF digestibility for calves on CS versus other forages. Calves on GH had greater $\mathrm{NDF}$ and $\mathrm{ADF}$ digestibility than those on $\mathrm{AH}$, as has been previously reported in lactating cows (Weiss and Shockey, 1991; Hoffman et al., 1998). Calves on GH had reduced DMI compared with those on $\mathrm{AH}$, which likely led to increased retention time within the rumen, allowing for greater fiber digestion. In a limit-feeding setting, it has also been observed that grass is broken down more slowly than alfalfa and retained within the rumen for a longer period of time (Waghorn et al., 1989).

Starch digestibility was reduced in calves consuming $\mathrm{AH}$ versus those consuming $\mathrm{CS}$ or $\mathrm{GH}$. The reason for this is not readily apparent. Weiss and Shockey (1991) observed similar reductions to the digestibility of total NSC when feeding cattle alfalfa versus orchardgrass (75.4 vs. $79.2 \%$, respectively). A potential explanation could be that calves on $\mathrm{AH}$ had greater passage rates of the concentrate fractions of the diet as a result of high DMI and rapidly degradable forage. Perhaps of greater concern is the relatively low level of starch digestibility observed regardless of forage $(\mathrm{AH}=88.2, \mathrm{CS}$ $=94.1, \mathrm{GH}=93.3)$. The corn used in this study was coarse cracked consisting primarily of whole kernels and halves.

\section{Ruminal Fermentation}

Rumen $\mathrm{pH}$ was unaffected by yeast supplementation (Table 6). This agrees with studies evaluating the effect of yeast supplementation on heifers at 18 mo (Lascano and Heinrichs, 2009) and 12 (Quigley et al., 1992), 4, and 8 wk of age (Xiao et al., 2016). However, a metaanalysis evaluating both large and small ruminants found that yeast supplementation increased rumen $\mathrm{pH}$ by 0.03 (Desnoyers et al., 2009), though the physiologi- cal effect of such a small change is likely negligible. Forage also did not have an effect on rumen $\mathrm{pH}$. However, there was a tendency for a yeast $\times$ forage interaction on mean rumen $\mathrm{pH}$. Yeast provision increased rumen $\mathrm{pH}$ of calves offered $\mathrm{GH}(+0.23)$, decreased rumen $\mathrm{pH}$ of calves offered $\mathrm{AH}(-0.19)$, and did not change rumen $\mathrm{pH}$ of calves offered CS. Reasons for this interaction are not readily apparent, but decreases in mean $\mathrm{pH}$ are consistent with numerical increases in total VFA, though there was no interaction between yeast and forage on total VFA. As calves aged, mean and minimum rumen $\mathrm{pH}$ tended to increase and increased, respectively. The increase is likely the result of increased forage intake as percent of DM for calves at $15 \mathrm{wk}$ of age. Increased forage intake would lead to increased rumination and salivation and thereby increase the buffering capacity of the rumen (McBurney et al., 1983). Another reason rumen $\mathrm{pH}$ would be lower for younger calves is if VFA production outpaced the absorptive capacity of the rumen epithelium (Williams et al., 1987). If this were the case, a similar increase in total VFA at 11 wk would be expected, but there was no effect of age on total VFA.

Figure $4 \mathrm{a}$ and $4 \mathrm{c}$ shows rumen $\mathrm{pH}$ relative to time after feeding. Calves on $\mathrm{GH}$ reached the nadir at $2 \mathrm{~h}$, and calves on $\mathrm{AH}$ and $\mathrm{CS}$ reached the nadir at $4 \mathrm{~h}$. This is likely because calves on GH consumed less forage in the initial TMR offering and therefore consumed the concentrate more quickly. It is also shown that rumen $\mathrm{pH}$ was higher for calves at 15 wk of age from 4 to 16 $h$ postfeeding.

Total VFA concentration was affected by the forage offered. Calves fed $\mathrm{AH}$ had greater levels of total VFA compared with CS and GH, and calves on CS and GH had comparable amounts of total VFA. The increased level of CP supplied by AH may have contributed to increased microbial growth (Van Soest, 1982), which may have been responsible for the increased total VFA observed for calves consuming AH versus CS or GH. Figure $4 \mathrm{~b}$ and $4 \mathrm{~d}$ shows how total VFA concentration changed over time, and it is clear that $\mathrm{AH}$ had higher total VFA concentration at all time points except for the peak between 4 and $8 \mathrm{~h}$ postfeeding, where VFA concentrations were equal regardless of forage. These results are in line with other studies that have observed increased total VFA concentration when feeding $\mathrm{AH}$ versus CS (Hristov and Broderick, 1996; Benchaar et al., 2007), as well as those that have seen no differences when feeding CS versus GH (Pino et al., 2018). We found no effects of yeast on total VFA, which agrees with Lascano et al. (2012) and Xiao et al. (2016). However, Lascano and Heinrichs (2009) found that yeast supplementation increased total VFA concentration in heifers near 17 mo of age. A meta-analysis of rumi- 


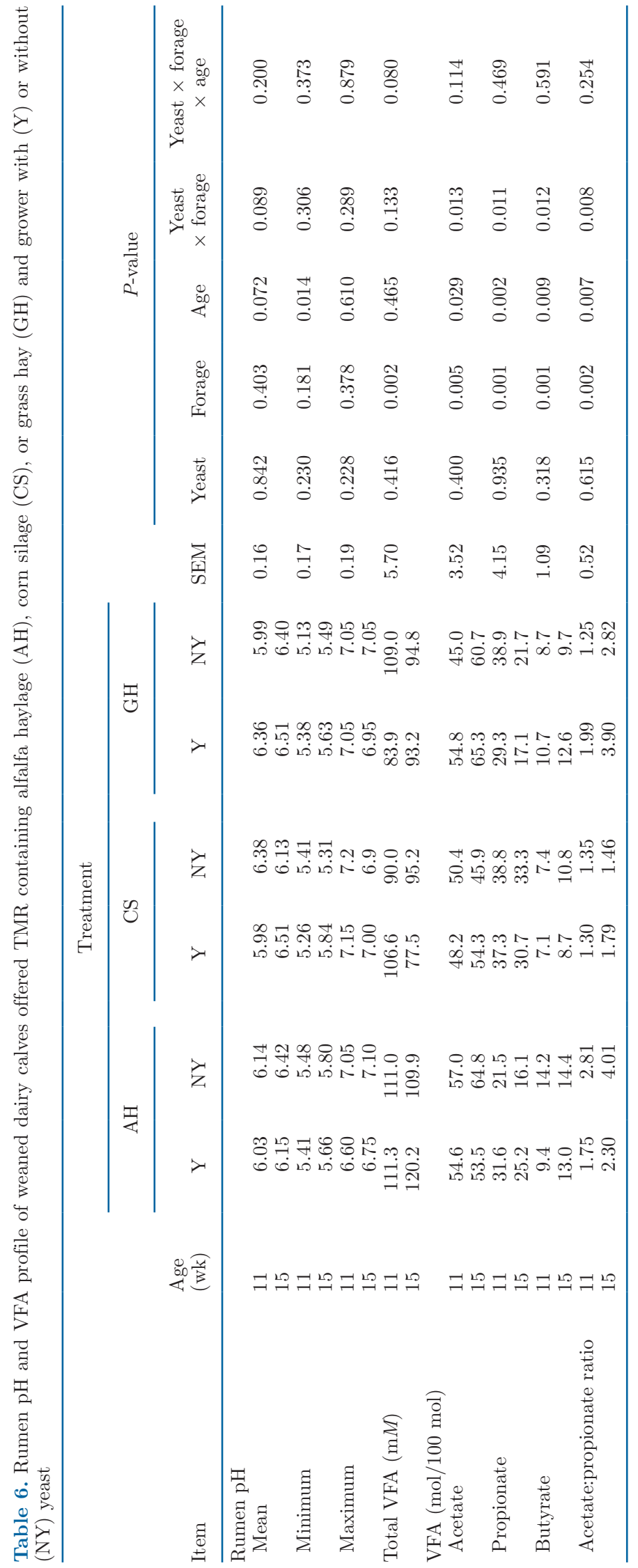



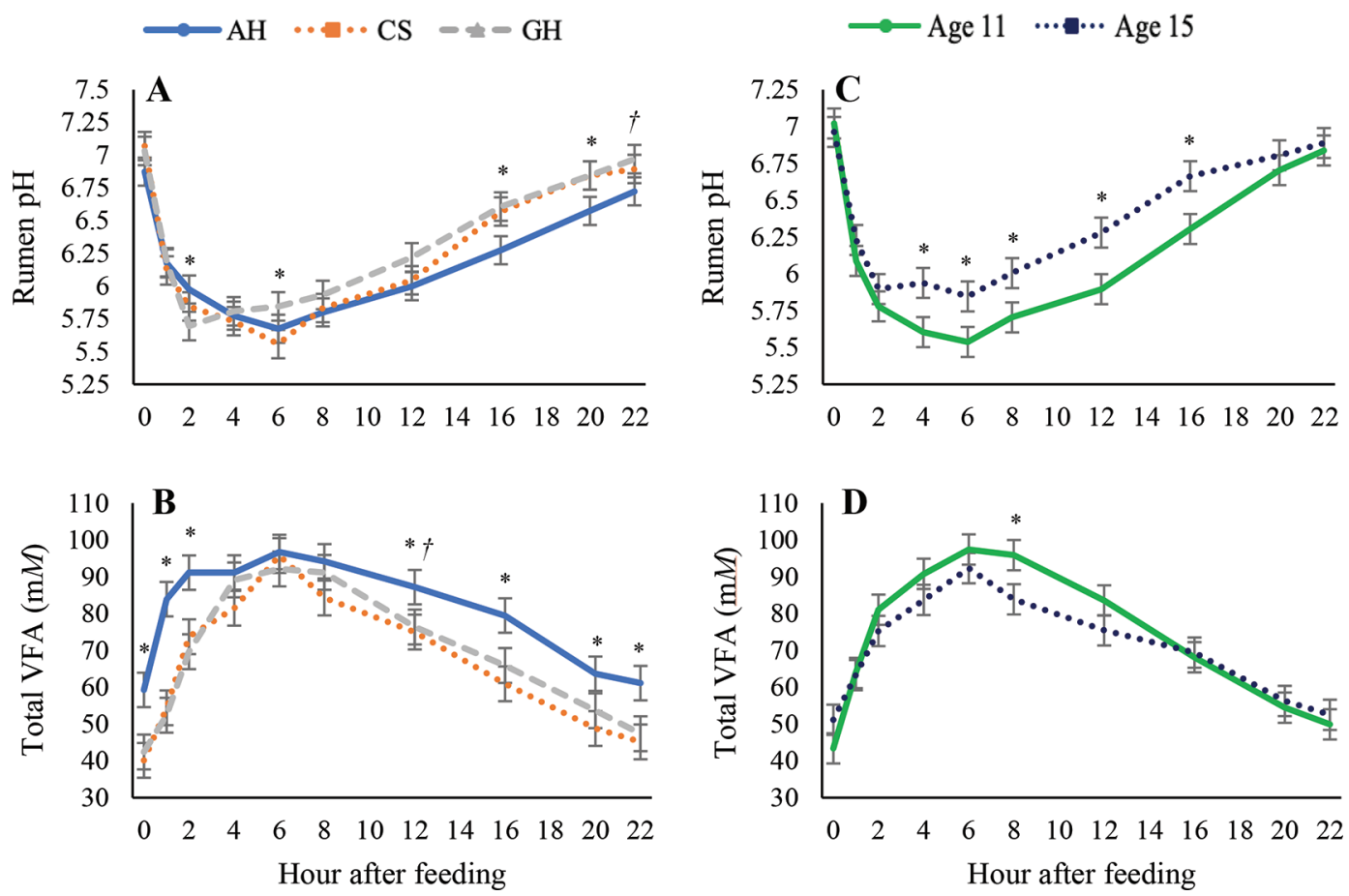

Figure 4. (A) Rumen $\mathrm{pH}$ of weaned dairy calves consuming different forages over time. *Signifies differences between groups at that time; $P \leq 0.05(2 \mathrm{~h} \mathrm{AH}>\mathrm{GH} ; 6 \mathrm{~h} \mathrm{GH}>\mathrm{CS} ; 16$ and $20 \mathrm{~h} \mathrm{CS}$ and $\mathrm{GH}>\mathrm{AH})$. †Signifies trends between groups at that time; $0.05<P \leq 0.1(22 \mathrm{~h}$ $\mathrm{GH}>\mathrm{AH}$ ). (B) Rumen VFA concentration of weaned dairy calves consuming different forages over time. * Signifies differences between groups at that time; $P \leq 0.05(0,2,4,16$, and $22 \mathrm{~h} \mathrm{AH}>\mathrm{CS}$ and $\mathrm{GH} ; 12$ and $20 \mathrm{~h} \mathrm{AH}>\mathrm{CS})$. †Signifies trends between groups at that time; $0.05<$ $P \leq 0.1(12 \mathrm{~h} \mathrm{AH}>\mathrm{GH})$. (C) Rumen $\mathrm{pH}$ of weaned dairy calves at different ages over time. *Signifies differences between groups at that time; $P \leq 0.05$. (D) Rumen VFA concentration of weaned dairy calves at different ages over time. *Signifies differences between groups at that time; $P \leq 0.05 . \mathrm{AH}=$ alfalfa haylage; $\mathrm{CS}=$ corn silage; $\mathrm{GH}=$ grass hay. Error bars represent $\pm \mathrm{SE}$.

nants in general found that VFA concentration $(\mathrm{m} M)$ increased from 95.2 to 97.3 with yeast addition (Desnoyers et al., 2009). Interestingly, there was a tendency for a triple interaction between yeast, forage, and age. Calves on $\mathrm{AH}$ had the highest and lowest total VFA at 15 wk on $\mathrm{Y}$ and $\mathrm{NY}$, respectively, but calves on GH had the highest and lowest total VFA at 11 wk on NY and $\mathrm{Y}$, respectively. Calves on CS had the highest and lowest total VFA on Y at 11 and $15 \mathrm{wk}$, respectively. Reasons for these different observations are unknown, and it is likely that they were simply due to chance. The triple interaction was comparing values obtained from a sample size of 2 , and thus the power is quite low.

Molar proportions of VFA were unaffected by yeast. These results are largely in agreement with that observed by Lascano and Heinrichs (2009) and Lascano et al. (2015). Lascano and Heinrichs (2009) observed that yeast decreased the proportion of butyrate. Lascano et al. (2015) observed no effects of yeast on butyrate, but they did observe a quadratic response of propionate proportion to increasing levels of yeast.

All VFA proportions evaluated in the present study were affected by forage, age, and a yeast $\times$ forage in- teraction. As expected, feeding CS resulted in the lowest molar proportion of acetate and the highest molar proportion of propionate. These results were expected as a result of higher in starch CS diets than $\mathrm{AH}$ and GH $(41.4 \%$ vs. 33.6 and $37.3 \%$, respectively). Similar observations have been made when feeding high- versus low-starch diets and when decreasing the forage to concentrate ratio in diets (Lascano and Heinrichs, 2009; Lascano et al., 2015). Interestingly, feeding CS also resulted in the lowest molar proportion of butyrate, and $\mathrm{AH}$ resulted in the greatest molar proportion of butyrate. Similar results have been reported when feeding AH and CS (Benchaar et al., 2007), but others have observed the opposite (Hristov and Broderick, 1996). Butyrate is primarily metabolized by the rumen epithelium into BHB before being transported to the blood (Bergman, 1990). Therefore, it could be expected that calves offered $\mathrm{AH}$ would have had the greatest levels of plasma BHB.

At 15 wk of age, acetate and butyrate increased and propionate decreased. This is directly tied to the observed increase in forage intake as percent of DMI as the calves aged. Lascano and Heinrichs (2009) observed 

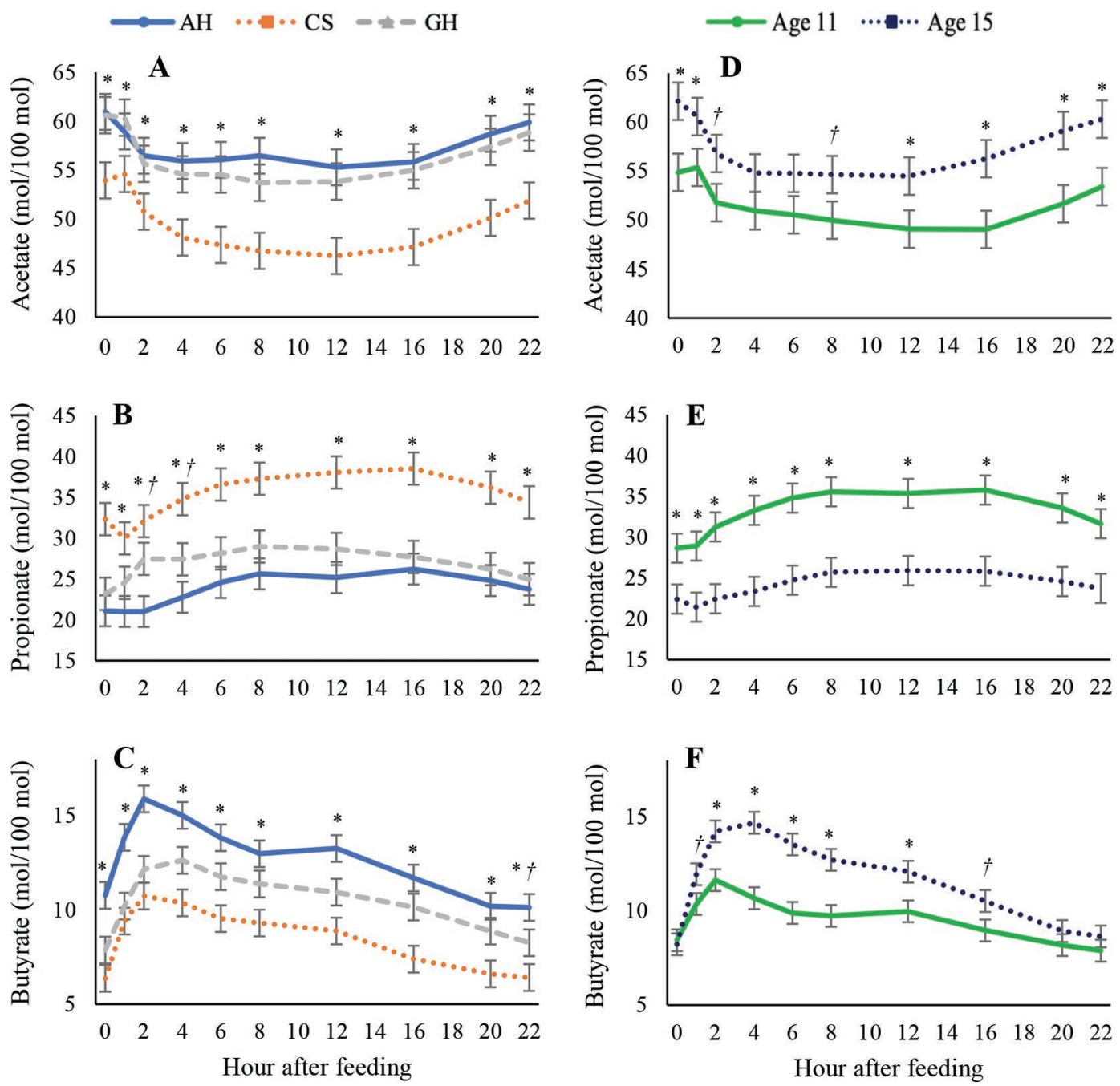

Figure 5. (A) Rumen acetate proportion for weaned dairy calves consuming different forages over time. * Signifies differences between groups at that time; $P \leq 0.05$ (at all time points $\mathrm{AH}$ and $\mathrm{GH}>\mathrm{CS}$ ). (B) Rumen propionate proportion for weaned dairy calves consuming different forages over time. *Signifies differences between groups at that time; $P \leq 0.05(0,1,4,6,8,12,16,20$, and $22 \mathrm{~h}$ CS $>$ AH and GH; $2 \mathrm{~h}$ CS and $\mathrm{GH}>\mathrm{AH})$. $\dagger$ Signifies trends between groups at that time; $0.05<P \leq 0.1$ ( $2 \mathrm{~h} \mathrm{CS}>\mathrm{GH} ; 4 \mathrm{~h} \mathrm{GH}>\mathrm{AH})$. (C) Rumen butyrate proportion for

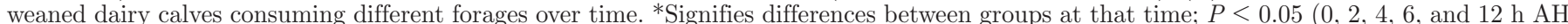
$>\mathrm{CS}$ and $\mathrm{GH} ; 4,6,8,12,16$, and $20 \mathrm{~h} \mathrm{AH}$ and $\mathrm{GH}>\mathrm{CS} ; 22 \mathrm{~h} \mathrm{AH}>\mathrm{CS})$. †Signifies trends between groups at that time; $0.05<P \leq 0.1(22 \mathrm{~h}$ $\mathrm{AH}>\mathrm{GH}$; GH > CS). (D) Rumen acetate proportion for weaned dairy calves at different ages over time. * Signifies differences between groups at that time; $P \leq 0.05$. $\dagger$ Signifies trends between groups at that time; $0.05<P \leq 0.1$. (E) Rumen propionate proportion of weaned dairy calves at different ages over time. * ${ }^{*}$ Signifies differences between groups at that time; $P \leq 0.05$. (F) Rumen butyrate proportion of weaned dairy calves at different ages over time. *Signifies differences between groups at that time; $P \leq 0.05$. †Signifies trends between groups at that time; $0.05<$ $P \leq 0.1 . \mathrm{AH}=$ alfalfa haylage; $\mathrm{CS}=$ corn silage; $\mathrm{GH}=$ grass hay. Error bars represent $\pm \mathrm{SE}$.

increasing acetate and decreasing propionate as they fed increasing forage to concentrate ratios.

There was also a yeast $x$ forage interaction observed for each VFA. Molar proportion of acetate decreased and propionate increased for calves on $\mathrm{YAH}$ versus NYAH. The opposite was true for calves on YGH versus NYGH, and there were no differences for calves on YCS versus NYCS. The reasons why yeast affected ruminal fermentation differently in diets containing $\mathrm{AH}$ or GH are not readily apparent. Molar proportion of
VFA was similar between $\mathrm{AH}$ and $\mathrm{GH}$, but it appears that inclusion of yeast may affect the ruminal bacterial communities differently depending on the type of forage offered.

Differences observed with molar proportions of acetate and propionate led to expected differences in the acetate to propionate ratio. Calves on CS had the lowest acetate to propionate ratio, and the acetate to propionate ratio increased at 15 wk of age. Figure 5 shows changes in the VFA proportion over time relative 
to feeding. Acetate decreased, propionate increased, and butyrate sharply increased 2 to $4 \mathrm{~h}$ postfeeding, at which point it gradually declined.

\section{CONCLUSIONS}

These results indicate that recently weaned calves can adapt to consume moderate amounts of forage and still accomplish adequate growth. Feeding GH versus $\mathrm{AH}$ or $\mathrm{CS}$ reduced DMI and ME intake, which led to decreased ADG and EBWG but only a tendency for reduced final BW. There were no differences in hip width, heart girth, or paunch girth regardless of forage. It is clear that calves in the age range of 7 to $16 \mathrm{wk}$ are rapidly developing and greatly expanding the capacity of their rumen. Calves were able to consume increasing levels of forage as DMI up to 44.4, 37.6, and $32.3 \%$ at 16 wk of age for $\mathrm{AH}, \mathrm{CS}$, and $\mathrm{GH}$, respectively, and still maintain adequate growth rates. Increasing forage intake increases rumen $\mathrm{pH}$, and offering different forages will change nutrient digestibility and VFA profile. Yeast supplementation did not have any effects on intake, growth, or nutrient digestibility for calves fed different forages from 7 to $16 \mathrm{wk}$. However, there were yeast $\times$ forage interaction effects on the VFA profile, indicating that yeast provision may alter microbial communities differently, depending on the forage fed. Based on these results, we conclude that under the conditions of this study, recently weaned calves are rapidly adapting to be able to consume moderate amounts of forage, and are capable of accomplishing growth goals when fed TMR containing a minimum of $20 \% \mathrm{AH}, 24.5 \% \mathrm{CS}$, or $11.3 \% \mathrm{GH}$.

\section{ACKNOWLEDGMENTS}

This research was a component of NC-2042; Management Systems to Improve the Economic and Environmental Sustainability of Dairy Enterprises. Funding was provided by The Pennsylvania State University, University Park. We thank Alltech (Nicholasville, KY) for providing the grower used in this trial and Massimiliano Festuccia from the University of Parma (Parma, Italy) for his help in data collection. The authors have not stated any conflicts of interest.

\section{REFERENCES}

Allen, M. S. 1996. Physical constraints on voluntary intake of forages by ruminants. J. Anim. Sci. 74:3063-3075. https://doi.org/10 $.2527 / 1996.74123063 x$.

Allen, M. S. 2000. Effects of diet on short-term regulation of feed intake by lactating dairy cattle. J. Dairy Sci. 83:1598-1624. https:// doi.org/10.3168/jds.S0022-0302(00)75030-2.

Allen, M. S., B. J. Bradford, and M. Oba. 2009. Board-invited review: The hepatic oxidation theory of the control of feed intake and its application to ruminants. J. Anim. Sci. 87:3317-3334. https://doi .org/10.2527/jas.2009-1779.

Alugongo, G. M., J. Xiao, Z. Wu, S. Li, Y. Wang, and Z. Cao. 2017. Utilization of yeast of Saccharomyces cerevisiae origin in artificially raised calves. J. Anim. Sci. Biotechnol. 8:34. https://doi.org/10 $.1186 / \mathrm{s} 40104-017-0165-5$.

AOAC International. 2000. Official Methods of Analysis, 17th ed. Association of Official Analytical Chemists, Gaithersburg, MD.

Benchaar, C., H. V. Petit, R. Berthiaume, D. R. Ouellet, J. Chiquette, and P. Y. Chouinard. 2007. Effects of essential oils on digestion ruminal fermentation, rumen microbial populations, milk production, and milk composition in dairy cows fed alfalfa silage or corn silage. J. Dairy Sci. 90:886-897. https://doi.org/10.3168/jds.S0022 -0302(07)71572-2.

Bergman, E. N. 1990. Energy contributions of volatile fatty acids from the gastrointestinal tract in various species. Physiol. Rev. 70:567590. https://doi.org/10.1152/physrev.1990.70.2.567.

Broderick, G. A. 1985. Alfalfa silage or hay versus corn silage as the sole forage for lactating dairy cows. J. Dairy Sci. 68:3262-3271. https://doi.org/10.3168/jds.S0022-0302(85)81235-2.

Callaway, E. S., and S. A. Martin. 1997. Effects of a Saccharomyces cerevisiae culture on ruminal bacteria that utilize lactate and digest cellulose. J. Dairy Sci. 80:2035-2044. https://doi.org/10 .3168/jds.S0022-0302(97)76148-4.

Castells, L., A. Bach, G. Araujo, C. Montoro, and M. Terre. 2012. Effect of different forage sources on performance and feeding behavior of Holstein calves. J. Dairy Sci. 95:286-293. https://doi.org/10 $.3168 /$ jds.2011-4405.

Castells, L., A. Bach, A. Aris, and M. Terré. 2013. Effects of forage provision to young calves on rumen fermentation and development of the gastrointestinal tract. J. Dairy Sci. 96:5226-5236. https:// doi.org/10.3168/jds.2012-6419.

Chaucheyras-Durand, F., N. D. Walker, and A. Bach. 2008. Effects of active dry yeasts on the rumen microbial ecosystem: Past, present and future. Anim. Feed Sci. Technol. 145:5-26. https://doi.org/10 .1016/j.anifeedsci.2007.04.019.

Colburn, M. W., J. L. Evans, and C. H. Ramage. 1968. Ingestion control in growing ruminant animals by the components of cell-wall constituents. J. Dairy Sci. 51:1458-1464. https://doi.org/10.3168/ jds.S0022-0302(68)87212-1.

Cooke, R. F., and J. D. Arthington. 2013. Concentrations of haptoglobin in bovine plasma determined by ELISA or a colorimetric method based on peroxidase activity. J. Anim. Physiol. Anim. Nutr. (Berl.) 97:531-536. https://doi.org/10.1111/j.1439-0396 2012.01298.x

Cumberland Valley Analytical Services Inc. 2011. Procedure references. Accessed Apr. 10, 2020. https://www.foragelab.com/Media/ CVAS_Proceedure_References.pdf.

Dennis, T. S., F. X. Suarez-Mena, T. M. Hill, J. D. Quigley, R. L. Schlotterbeck, and G. J. Lascano. 2018. Short communication: Effect of replacing corn with beet pulp in a high concentrate diet fed to weaned Holstein calves on diet digestibility and growth. J. Dairy Sci. 101:408-412. https://doi.org/10.3168/jds.2017-13292.

Desnoyers, M., S. Giger-Reverdin, G. Bertin, C. Duvaux-Ponter, and D. Sauvant. 2009. Meta-analysis of the influence of Saccharomyces cerevisiae supplementation on ruminal parameters and milk production of ruminants. J. Dairy Sci. 92:1620-1632. https://doi.org/ $10.3168 /$ jds.2008-1414.

Dhiman, T. R., and L. D. Satter. 1997. Yield response of dairy cows fed different proportions of alfalfa silage and corn silage. J. Dairy Sci. 80:2069-2082. https://doi.org/10.3168/jds.S0022-0302(97)76152 $-6$.

Dingwell, R. T., M. M. Wallace, C. J. McLaren, C. F. Leslie, and K. E. Leslie. 2006. An evaluation of two indirect methods of estimating body weight in Holstein calves and heifers. J. Dairy Sci. 89:39923998. https://doi.org/10.3168/jds.S0022-0302(06)72442-0.

Galvão, K. N., J. E. P. Santos, A. Coscioni, M. Villaseñor, W. M Sischo, and A. C. B. Berge. 2005. Effect of feeding live yeast products to calves with failure of passive transfer on performance and patterns of antibiotic resistance in fecal Escherichia coli. Reprod. Nutr. Dev. 45:427-440. https://doi.org/10.1051/rnd:2005040. 
Gelsinger, S. L., F. Pino, C. M. Jones, A. M. Gehman, and A. J. Heinrichs. 2016. Effects of a dietary organic mineral program including mannan oligosaccharides for pregnant cattle and their calves on calf health and performance. Prof. Anim. Sci. 32:205-213. https:/ /doi.org/10.15232/pas.2015-01475.

Hall, M. B. 2009. Determination of starch, including maltooligosaccharides, in animal feeds: Comparison of methods and a method recommended for AOAC collaborative study. J. AOAC Int. 92:42-49. https://doi.org/10.1093/jaoac/92.1.42.

Heinrichs, A. J. 1996. Nutrition and management of replacement cattle. Anim. Feed Sci. Technol. 59:155-166. https://doi.org/10.1016/ 0377-8401(95)00896-9.

Heinrichs, A. J., C. M. Jones, S. M. Gray, P. A. Heinrichs, S. A. Cornelisse, and R. C. Goodling. 2013. Identifying efficient dairy heifer producers using production costs and data envelopment analysis. J. Dairy Sci. 96:7355-7362. https://doi.org/10.3168/jds.2012-6488.

Heinrichs, A. J., and W. C. Losinger. 1998. Growth of Holstein dairy heifers in the United States. J. Anim. Sci. 76:1254-1260. https:// doi.org/10.2527/1998.7651254x.

Heinrichs, A. J., G. W. Rogers, and J. B. Cooper. 1992. Predicting body weight and wither height in Holstein heifers using body measurements. J. Dairy Sci. 75:3576-3581. https://doi.org/10.3168/ jds.S0022-0302(92)78134-X.

Hill, S. R., B. A. Hopkins, S. Davidson, S. M. Bolt, D. E. Diaz, C. Brownie, T. Brown, G. B. Huntington, and L. W. Whitlow. 2009a. The addition of cottonseed hulls to the starter and supplementation of live yeast or mannanoligosaccharide in the milk for young calves. J. Dairy Sci. 92:790-798. https://doi.org/10.3168/jds.2008 -1320 .

Hill, T. M., H. G. Bateman II, J. M. Aldrich, and R. L. Schlotterbeck. 2008. Effects of the amount of chopped hay or cottonseed hulls in a textured calf starter on young calf performance. J. Dairy Sci. 91:2684-2693. https://doi.org/10.3168/jds.2007-0935.

Hill, T. M., H. G. Bateman Ii., J. M. Aldrich, and R. L. Schlotterbeck. 2009b. Roughage for diets fed to weaned dairy calves. Prof. Anim. Sci. 25:283-288. https://doi.org/10.15232/S1080-7446(15)30719-1.

Hill, T. M., H. G. Bateman II, J. M. Aldrich, and R. L. Schlotterbeck. 2010. Roughage amount, source, and processing for diets fed to weaned dairy calves. Prof. Anim. Sci. 26:181-187. https://doi.org/ 10.15232/S1080-7446(15)30578-7.

Hoffman, P. C., D. K. Combs, and M. D. Casler. 1998. Performance of lactating dairy cows fed alfalfa silage or perennial ryegrass silage. J. Dairy Sci. 81:162-168. https://doi.org/10.3168/jds.S0022 -0302(98)75563-8.

Hoffman, P. C., K. A. Weigel, and R. M. Wernberg. 2008. Evaluation of equations to predict dry matter intake of dairy heifers. J. Dairy Sci. 91:3699-3709. https://doi.org/10.3168/jds.2007-0644.

Hristov, A. N., and G. A. Broderick. 1996. Synthesis of microbial protein in ruminally cannulated cows fed alfalfa silage, alfalfa hay, or corn silage. J. Dairy Sci. 79:1627-1637. https://doi.org/10.3168/ jds.S0022-0302(96)76526-8.

Hučko, B., V. A. Bampidis, A. Kodeš, V. Christodoulou, Z. Mudřik, K. Poláková, and V. Plachý. 2009. Rumen fermentation characteristics in pre-weaning calves receiving yeast culture supplements. Czech J. Anim. Sci. 54:435-442. https://doi.org/10.17221/1674 -CJAS.

Huntington, G. B., and S. L. Archibeque. 2000. Practical aspects of urea and ammonia metabolism in ruminants. J. Anim. Sci. 77(ESuppl.):1-11. https://doi.org/10.2527/jas2000.77E-Suppl1y.

Imani, M., M. Mirzaei, B. Baghbanzadeh-Nobari, and M. H. Ghaffari. 2017. Effects of forage provision to dairy calves on growth performance and rumen fermentation: A meta-analysis and metaregression. J. Dairy Sci. 100:1136-1150. https://doi.org/10.3168/ jds.2016-11561.

Jahn, E., and P. T. Chandler. 1976. Performance and nutrient requirements of calves fed varying percentages of protein and fiber. J. Anim. Sci. 42:724-735. https://doi.org/10.2527/jas1976.423724x.

Lascano, G. J., and A. J. Heinrichs. 2009. Rumen fermentation pattern of dairy heifers fed restricted amounts of low, medium, and high concentrate diets without and with yeast culture. Livest. Sci. 124:48-57. https://doi.org/10.1016/j.livsci.2008.12.007.
Lascano, G. J., A. J. Heinrichs, and J. M. Tricarico. 2012. Substitution of starch by soluble fiber and Saccharomyces cerevisiae dose response on nutrient digestion and blood metabolites for precisionfed dairy heifers. J. Dairy Sci. 95:3298-3309. https://doi.org/10 .3168/jds.2011-5047.

Lascano, G. J., A. J. Heinrichs, and J. M. Tricarico. 2015. Saccharomyces cerevisiae live culture affects rapidly fermentable carbohydrates fermentation profile in precision-fed dairy heifers. Can. J. Anim. Sci. 95:117-127. https://doi.org/10.4141/cjas-2014-104.

Lesmeister, K. E., and A. J. Heinrichs. 2004. Effects of corn processing on growth characteristics, rumen development, and rumen parameters in neonatal dairy calves. J. Dairy Sci. 87:3439-3450. https:// doi.org/10.3168/jds.S0022-0302(04)73479-7.

Lesmeister, K. E., A. J. Heinrichs, and M. T. Gabler. 2004. Effects of supplemental yeast (Saccharomyces cerevisiae) culture on rumen development, growth characteristics, and blood parameters in neonatal dairy calves. J. Dairy Sci. 87:1832-1839. https://doi.org/10 .3168/jds.S0022-0302(04)73340-8.

Magalhães, V. J. A., F. Susca, F. S. Lima, A. F. Branco, I. Yoon, and J. E. P. Santos. 2008. Effect of feeding yeast culture on performance, health, and immunocompetence of dairy calves. J. Dairy Sci. 91:1497-1509. https://doi.org/10.3168/jds.2007-0582.

McBurney, M. I., P. J. Van Soest, and L. E. Chase. 1983. Cation exchange capacity and buffering capacity of neutral-detergent fibres. J. Sci. Food Agric. 34:910-916. https://doi.org/10.1002/jsfa .2740340903 .

Mitchell, L. K., C. M. Jones, and A. J. Heinrichs. 2020. Effect of converting weaned dairy calves from a component-fed diet to a total mixed ration on growth and nutrient digestibility. J. Dairy Sci 103:6190-6199. https://doi.org/10.3168/jds.2019-17980.

Moser, E. B. 2004. Repeated measures modeling with PROC MIXED. Pages 9-12. SAS Inst., Cary, NC.

NRC. 2001. Nutrient Requirements of Dairy Cattle. 7th rev. ed. National Academy of Sciences, Washington, DC.

Omidi-Mirzaei, H., A. Azarfar, M. Mirzaei, A. Kiani, and M. H. Ghaffari. 2018. Effects of forage source and forage particle size as a free-choice provision on growth performance, rumen fermentation, and behavior of dairy calves fed texturized starters. J. Dairy Sci. 101:4143-4157. https://doi.org/10.3168/jds.2017-13990.

Panda, A. K., R. Singh, and N. N. Pathak. 1995. Effect of dietary inclusion of Saccharomyces cerevisiae on growth performance of crossbred calves. J. Appl. Anim. Res. 7:195-200. https://doi.org/ 10.1080/09712119.1995.9706071.

Pino, F., L. K. Mitchell, C. M. Jones, and A. J. Heinrichs. 2018. Comparison of diet digestibility, rumen fermentation, rumen rate of passage, and feed efficiency in dairy heifers fed ad-libitum versus precision diets with low and high quality forages. J. Appl. Anim. Res. 46:1296-1306. https://doi.org/10.1080/09712119.2018 .1498788 .

Quigley, J. D. III, L. Wallis, H. Dowlen, and R. Heitmann. 1992. Sodium bicarbonate and yeast culture effects on ruminal fermentation, growth, and intake in dairy calves. J. Dairy Sci. 75:3531-3538. https://doi.org/10.3168/jds.S0022-0302(92)78129-6.

Quigley, J. D., W. Hu, J. R. Knapp, T. S. Dennis, F. X. Suarez-Mena, and T. M. Hill. 2019. Estimates of calf starter energy affected by consumption of nutrients. 2. Effect of changing digestion on energy content in calf starters. J. Dairy Sci. 102:2242-2253. https://doi .org/10.3168/jds.2018-15354.

Robinson, P. H., and L. J. Erasmus. 2009. Effects of analyzable diet components on responses of lactating dairy cows to Saccharomyces cerevisiae based yeast products: A systematic review of the literature. Anim. Feed Sci. Technol. 149:185-198. https://doi.org/10 .1016/j.anifeedsci.2008.10.003.

Saldana, D. J., C. M. Jones, A. M. Gehman, and A. J. Heinrichs. 2019. Effects of once- versus twice-a-day feeding of pasteurized milk supplemented with yeast-derived feed additives on growth and health in female dairy calves. J. Dairy Sci. 102:3654-3660. https://doi.org/10.3168/jds.2018-15695.

USDA. 2014. Dairy 2014: Dairy Cattle Management Practices in the United States, 2014. USDA-APHIS-VS-CEAH-NAHMS, Fort Collins, CO. 
Van Soest, P. J., J. B. Robertson, and B. A. Lewis. 1991. Methods for dietary fiber, neutral detergent fiber, and nonstarch polysaccharides in relation to animal nutrition. J. Dairy Sci. 74:3583-3597. https://doi.org/10.3168/jds.S0022-0302(91)78551-2.

Van Soest, P. J. 1965. Symposium on factors influencing the voluntary intake of herbage by ruminants: Voluntary intake in relation to chemical composition and digestibility. J. Anim. Sci. 24:834-843. https://doi.org/10.2527/jas1965.243834x.

Van Soest, P. J. 1982. Nutritional Ecology of the Ruminant. O \& B Books Inc., Corvalis, OR.

Waghorn, G. C., I. D. Shelton, and V. J. Thomas. 1989. Particle breakdown and rumen digestion of fresh ryegrass (Lolium perenne L.) and lucerne (Medicago sativa L.) fed to cows during a restricted feeding period. Br. J. Nutr. 61:409-423. https://doi.org/10.1079/ BJN19890127.

Weiss, W. P., and W. L. Shockey. 1991. Value of orchardgrass and alfalfa silages fed with varying amounts of concentrates to dairy cows. J. Dairy Sci. 74:1933-1943. https://doi.org/10.3168/jds .S0022-0302(91) 78359-8.

Williams, P. E. V., R. J. Fallon, G. M. Innes, and P. Garthwaite. 1987. Effects on food intake, rumen development and live weight of calves of replacing barley with sugar beet-citrus pulp in a starter diet. Anim. Sci. 44:65-73. https://doi.org/10.1017/S0003356100028075.

Xiao, J. X., G. M. Alugongo, R. Chung, S. Z. Dong, S. L. Li, I. Yoon, Z. H. Wu, and Z. J. Cao. 2016. Effects of Saccharomyces cerevisiae fermentation products on dairy calves: Ruminal fermentation, gastrointestinal morphology, and microbial community. J. Dairy Sci 99:5401-5412. https://doi.org/10.3168/jds.2015-10563.

Yang, C. M. J., and G. A. Varga. 1989. Effect of three concentrate feeding frequencies on rumen protozoa, rumen digesta kinetics, and milk yield in dairy cows. J. Dairy Sci. 72:950-957. https://doi .org/10.3168/jds.S0022-0302(89)79188-8.

Zanton, G. I., and A. J. Heinrichs. 2007. The effects of controlled feeding of a high-forage or high-concentrate ration on heifer growth and first-lactation milk production. J. Dairy Sci. 90:3388-3396. https://doi.org/10.3168/jds.2007-0041.

Zanton, G. I., and A. J. Heinrichs. 2009. Digestion and nitrogen utilization in dairy heifers limit-fed a low or high forage ration at four levels of nitrogen intake. J. Dairy Sci. 92:2078-2094. https://doi .org/10.3168/jds.2008-1712. 